Columbia Law School

Scholarship Archive

2022

\title{
Shifting Influences on Corporate Governance: Capital Market Completeness and Policy Channeling
}

Ronald J. Gilson

Columbia Law School, rgilson@law.columbia.edu

Curtis J. Milhaupt

Stanford Law School, milhaupt@law.stanford.edu

Follow this and additional works at: https://scholarship.law.columbia.edu/faculty_scholarship

Part of the Business Organizations Law Commons, and the Securities Law Commons

\section{Recommended Citation}

Ronald J. Gilson \& Curtis J. Milhaupt, Shifting Influences on Corporate Governance: Capital Market Completeness and Policy Channeling, 12 HARV. Bus. L. REV. 1 (2022).

Available at: https://scholarship.law.columbia.edu/faculty_scholarship/2705

This Article is brought to you for free and open access by the Faculty Publications at Scholarship Archive. It has been accepted for inclusion in Faculty Scholarship by an authorized administrator of Scholarship Archive. For more information, please contact scholarshiparchive@law.columbia.edu. 


\title{
SHIFTING INFLUENCES ON CORPORATE GOVERNANCE: CAPITAL MARKET COMPLETENESS AND POLICY CHANNELING
}

\author{
Ronald J. Gilson* and Curtis J. Milhaupt**
}

\author{
History doesn't repeat itself, but it often rhymes \\ - typically attributed to Mark Twain
}

\begin{abstract}
Corporate governance scholarship is typically portrayed as driven by single factor models, for example, shareholder value maximization, director primacy or team production. These governance models are Copernican; one factor is or should be the center of the corporate governance solar system. In this essay, we argue that, as with binary stars, the shape of the governance system is at any time the result of the interaction of two central influences, which we refer to as capital market completeness and policy channeling. In contrast to single factor models, which reflect a stable normative statement of what should drive corporate governance, in our account the relation between these two governance influences is dynamic.
\end{abstract}

Motivated by Albert Hirschman's Shifting Involvements, we posit that all corporate governance systems undergo repeated shifts in the relative weights of the two influences on the system. Capital market completeness determines the corporate ownership structure and privileges shareholder governance and value maximization by increasing the capacity to slice risk, return, and control into different equity instruments. The capability to specify shareholder control rights makes the capital market more complete, tailoring the character of influence associated with holding particular equity securities and its reciprocal, the exposure of management to capital market oversight. Policy channeling, the instrumental use of the corporation for distributional or social ends, pushes the corporate governance gravitational center toward purposes other than maximizing shareholder value.

We show that this pattern is not limited to a particular country, and illustrate our argument by tracing the cyclical reframing of Berle and Means' thesis in the U.S., Japan's sluggish shift from policy channeling in its post-war heyday toward capital market completeness under the Abenomics reforms, and the distinctive case of China, where capital market completeness has itself been used as a policy channeling instrument under the pervasive influence of the Chinese Communist Party, creating the world's most stakeholder-oriented system of corporate governance. The consistency of the pattern of shifting influences across

* Mark \& Eva Stern Professor of Law and Business, Columbia Law School; Meyers Professor of Law and Business emeritus, Stanford Law School; European Corporate Governance Institute.

** William F. Baxter-Visa International Professor of Law, Stanford Law School; European Corporate Governance Institute. The authors are grateful for helpful comments from Peter Conti-Brown, Jeffrey Gordon, Zohar Goshen, Gen Goto, Henry Hansmann, Michael Klausner, Dan Puchniak, Edward Rock, Leo Strine, Jr., and participants at workshops at Columbia Law School, the University of Texas School of Law, the Comparative Law Works in Progress Workshop at Princeton University, and the 2021 Asian Law and Economics Association Conference. 
countries with very different business and corporate systems, and across different periods of time, provides support for the dynamic pattern we describe.

We close by examining the means through which the current shift toward policy channeling in U.S. and U.K. corporate governance is taking place - the "stewardship" movement and the debate over "corporate purpose." We view both as a reaction to the reduced managerial discretion caused by the reconcentration of ownership in the hands of institutional investors, and analyze factors suggesting that this reform movement, like others before it, is likely destined to result in a disappointment-driven movement in the opposite direction, what we label a shifting influence.

\section{TABLe of Contents}

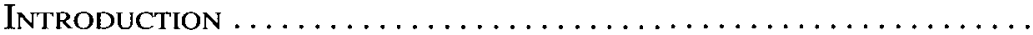

I. The Binary Influences on Corporate Governance:

Market Completeness and Policy Channeling ........ 8

A. Market Completeness ......................... 8

B. Policy Channeling .......................... 10

C. Endogenous Shifts Between Capital Market Completeness and Policy Channeling ......................... 12

II. Cycles in U.S. Corporate Governance .............. 13

A. From Legislative Chartering to General Incorporation Regimes ............................... 13

B. The Cyclical Reframing of Berle and Means.......... 17

C. Summary Japan: From Policy Channeling to Shareholder Capitalism ................................ 23

III. Governance Cycles Outside the U.S. .............. 23

A. Japan: From Policy Channeling to Shareholder Capitalism ............................... 24

B. China: State Ownership and Policy Channeling....... 30

C. Conclusion ................................ 37

IV. Where in the Governance Cycle are We Now? ....... 38

A. The First Channel: Stewardship ................ 39

B. The Second Channel: Corporate Purpose........... 49

Conclusion....................................... 53

\section{INTRODUCTION}

Corporate governance scholarship is typically portrayed as driven by one or another single factor model, for example, shareholder value maximization, director primacy, or team production. Each sees the governance model as Copernican; one factor is or should be the center of the corporate 
governance solar system, around which all others revolve.' In this essay, we argue that the shape of the governance system is at any time the result of the interaction of two central influences, which we will refer to as capital market completeness and policy channeling.

A metaphor from astrophysics illustrates the point. Some stars that at a distance appear to be a single object are on closer examination actually part of a binary system: two stars revolving in relation to one another, where their individual orbits are influenced by their interaction. We argue here that "corporate governance" is better understood as the solution, at any point in time, to the governance equivalent of what astrophysicists refer to as the two-body problem: the interaction between two stars in a binary system.

In corporate governance terms, the two forces whose influences must be balanced are, on the one hand, the level of capital market completeness, and on the other, policy channeling. As we will develop, capital market completeness determines the corporate ownership structure: the more complete the capital market (whether through the proliferation of new financial instruments to transfer risk or through the availability of additional techniques that allow the control rights associated with equity securities to be tailored), the more responsive governance will be to shareholders and to maximizing shareholder value. On the other hand, policy channeling, the instrumental use of the corporation for economic policy or social purposes (whether through corporate law and governance rules, the regulation of the capital market, outright state ownership of corporate securities, or through indirect state influence not measured by the size of the state's ownership), pushes the corporate governance gravitational center toward achieving purposes other than maximizing shareholder value. ${ }^{2}$ As with the orbits of binary stars, the balance between the influence of capital market completeness and government policy channeling on corporate governance is shaped at any point in time by the relative "weights" of the two influences.

Central to our analysis is the observation that the relation between these two governance influences is dynamic. Changes in one of the factors affect the other in a predictable direction. We submit that the corporate governance system is the subject of cycles in which shifts in the gravitational balance of the two combined forces derive from changes in each.

In our exploration of cycles in corporate governance between an emphasis on shareholder value and on other elements of policy, we draw explicitly on one of Albert Hirschman's less appreciated works, Shifting

'See Ronald J. Gilson, From Corporate Law to Corporate Governance, in OxFORD Handbook or Corporate Law and Governance 3 (Jeffrey N. Gordon \& Wolf-Georg Ringe eds., 2018).

${ }^{2}$ Curtis J. Milhaupt \& Mariana Pargendler, Related Party Transactions in State-Owned

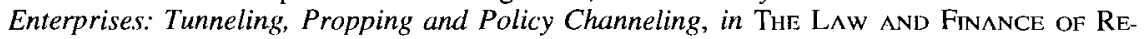
lated Party Transactions 245 (Luca Enriques \& Tobias H. Tröger eds., 2019), first develop the concept of policy channeling as a corporate governance strategy. 
Involvements: Private Interest and Public Action. ${ }^{3}$ We use Hirschman's framework to highlight the dynamics of different directional influences on corporate governance, rather than the typical static account of the governance system - a snapshot at a point in time of what is in fact a moving picture. In Shifting Involvements, Hirschman recounts a continuous cycling between an individual's engagement in private as opposed to public affairs, where the cycles are driven by disappointment with the utility ultimately experienced, as opposed to anticipated, by one or the other activity. The difference between the expected utility, as opposed to that actually realized, from engaging in either private or public-oriented activities results in a rebound in the opposite direction and so drives the repeated cycle.

In our extension of Hirschman's cyclical interaction between private and public utility, the dominant driver of corporate governance shifts is the interaction between the influence on corporate governance of increased capital market completeness and the resulting emphasis on shareholder value maximization, and "real" governance-influenced policy channeling in response to the corporation's impact on non-shareholders. In Hirschman's account, personal disappointment is the driver of cycles of individual human behavior; in the realm of commercial and organizational behavior, the driver is disappointment with corporate performance, either in the form of financial returns for shareholders or the realization of non-financial objectives for a broader group of stakeholders. Disappointment in this context may result from a level of social or political disenchantment with the prevailing balance in the governance system, unrealistic expectations about what a given corporate governance reform can accomplish, or from the selection of mechanisms incapable of achieving a desired result. Both the actors involved in the effort to shift the balance between the two influences and the mechanisms chosen to accomplish the shift will vary over time and across different governance systems.

Which governance reforms command attention at a particular moment in time then depends importantly on context: where a particular country is located in the Hirschman-like governance cycle and accordingly the effect of the interaction between changes in the capital market and the intervention of real governance into corporate governance. If this characterization of the dynamics of the governance system is right, policy analysis becomes significantly more contextual. To take just one example of the importance of context in understanding these cyclical shifts, as we discuss in Part III, Japan has been moving sluggishly from extreme policy channeling toward shareholder value maximization at a time when many are urging a broader stakeholder orientation for U.S. and U.K. corporate governance.

Consider the current corporate governance debate in the U.S. and the U.K., framed by the tension between a system driven by maximizing share-

${ }^{3}$ Al.birkt O. Hirschman, Shifting Involvements: Private: Interest and Public ACTION (1982). 
holder value, and a stakeholder system that focuses on how the governance system can be used instrumentally to influence the distribution of the value created by corporate activity among all those affected by it. Colin Mayer's recent writings, ${ }^{4}$ stressing the need to reinvent the public corporation, his leadership of the current British Academy project on the future of the corporation, which seeks to accomplish "a radical reformulation of the concept of the firm,"s and Martin Lipton's "new paradigm," reflect the views of both a leading academic and those of an influential practitioner that a corporation should have a broader purpose than simply maximizing shareholder value. Larry Fink, CEO of BlackRock, the largest U.S. institutional investor, ${ }^{7}$ has echoed the theme in his yearly missives to senior management of BlackRock's portfolio companies. ${ }^{8}$

The corporate governance cycle between a focus on shareholder value maximization and a broader concern over diverse stakeholders is also illustrated nicely by the Business Roundtable's repeated shifts in its framing of the purpose of the corporation. The Roundtable's 1978 and 1981 statements tried to walk a careful line between the competing claims of shareholders and stakeholders. The 1981 statement explained that "balancing the shareholder's expectations of maximum return against other priorities is one of the fundamental problems confronting corporate management. The shareholders must receive a good return, but the legitimate concerns of other constituencies also must have appropriate attention." Then eighteen years later, in 1997, the Roundtable moved to a clear shareholder value maximization framing: "the principal objective of a business enterprise is to generate eco-

${ }^{4}$ See, e.g., Colin Mayer, Prosperity: Be'trter Business Makes the Greater Gool (2018); Colin Mayer, Firm Commitment: Why the Corporation is Falling Us and What to Do ABour IT (2018).

${ }^{5}$ Brit. Acad., Reforming Business for the 21 st Cenjury: A Framework for the Future of THE Corporation 5 (2018).

${ }^{6}$ Martin Lipton, Corporate Governance: The New Paradigm, Harv. L. SCH. F. ON Corp. GovernanCE (Jan. 11, 2017) https://corpgov.law.harvard.edu/2017/01/11/corporate-govern ance-the-new-paradigm/.

${ }^{7}$ Tim Lemke, The Ten Largest Investment Management Companies Worldwide, THE BALANCE (Apr. 9, 2020), https://www.thebalance.com/which-firms-have-the-most-assets-undermanagement-4173923.

${ }^{8}$ Larry Fink, A Sense of Purpose, Harv. L. Sch. F. On Corp. Governance (Jan. 17, 2018), https://corpgov.law.harvard.edu/2018/01/17/a-sense-of-purpose/. Most recently, see the 2022 edition: Larry Fink's Annual Letter to CEOs: The Power of Capitalism, BLACKROCK) https://www.blackrock.com/corporate/investor-relations/larry-finkceo.)letter?cid=ppc:blk:ll: na:ol:goog:na:v2:bhv:tl\&gclid $=5581 \mathrm{c} 76 \mathrm{ff} 49615 \mathrm{a} 8 \mathrm{e} 83 \mathrm{fa} 683 \mathrm{fbfb} 287 \mathrm{c} \& \mathrm{gclsrc}=3 \mathrm{p} . \mathrm{ds}$, (last visited Feb. 8, 2022).

${ }^{9}$ The Bus. Rounitabie, Statement on the Purpose of the Corporatton (1981). The 1978 Statement tried to walk roughly the same line: "It is the board's duty to consider the overall impact of the activities of the corporation on (1) the society of which it is a part, and on (2) the interests and views of groups other than those immediately identified with the corporation. This obligation arises out of the responsibility to act primarily in the interest of the share owners-particularly their long-range interest." The Business Roundtable, The Role and Composition of the Board of Directors of the Large Publicly Owned Corporation, 33 Bus. L. 2086 (1978). The Business Roundtable is comprised of the CEOs of 181 of the largest U.S. publicly traded corporations. 
nomic returns to its owners," 10 only to bounce back a dozen years later with a broader 2019 framing of the corporation's obligation: "a fundamental commitment to all of our stakeholders."1 In explaining the 2019 move back to a stakeholder orientation, the Roundtable frankly explained that its 1997 shift toward shareholder value maximization had been "partly in response to growing pressures from corporate raiders." 12 Its 2019 return to a broader framing that encompasses concern with a lengthy list of stakeholders was said to "better reflect the way corporations can and should operate today." 13 We thus see a cycle moving from a broad to a narrow statement of corporate purpose and back again, now entering the political arena as evidenced, for example, by Senator Elizabeth Warren's proposed Accountable Capitalism Act as part of her campaign for the Democratic 2020 Presidential nomination. ${ }^{14}$

Following Hirschman, in this essay we offer a loose analytic narrative ${ }^{15}$ - one that does not specify outcomes, but rather identifies the contending elements of the tradeoff driving corporate governance cyclicality and affecting its direction and trajectory. In short, our ambition is to improve the analytics of the current corporate governance debate, rather than to predict with precision specific outcomes, which will differ from country to country and from time to time, depending on the then-current position in a country's governance cycle and on the parties or market forces behind the shifting influences. To make headway on understanding corporate governance shifts, the analytics have to be right before more rigorous modeling or empirical work-ultimately central to prediction-is possible. ${ }^{16}$ Particularly when preferences can be in significant respect non-pecuniary, and where path de-

${ }^{10}$ The Bus. Roundtable, Statement on the Purpose of the Corporation 3 (1997) ("In the Business Roundtable's view, the paramount duty of management and of boards of directors is to the corporate stockholders; the interests of other stakeholders are relevant as a derivative of the duty to stockholders.").

${ }^{11}$ The Bus. Roundtable, Statement on the Purpose of the Corporation (Aug. 19, 2019), https://s3.amazonaws.com/brt.org/BRT-StatementonthePurposeofaCorporationJuly2021.pdf (emphasis in the original).

${ }^{12}$ Id. Remarkably, the Roundtable's account does not address why corporate raiders influenced the Roundtable's assessment of its principles, or why the change reflected in the sentence might reduce the pressure.

${ }^{13}$ Press Release, The Bus. Roundtable, Business Roundtable Redefines the Purpose of a Corporation to Promote 'An Economy That Serves All Americans' (Aug. 19, 2019), https:// www.businessroundtable.org/business-roundtable-redefines-the-purpose-of-a-corporation-topromote-an-economy-that-serves-all-americans.

${ }^{14}$ Accountable Capitalism Act, S. 3348, 115th Cong. \$ 6 (2018). Among other features, Senator Warren's proposal would require that $40 \%$ of the board of directors of companies with $\$ 1$ billion in gross revenues be selected by employees. Senator Sanders proposed similar legislation (45\% of the board elected by employees) but covered a broader range of companies: publicly traded companies with more than $\$ 100$ million in assets or revenues. Bernie Sanders, Corporate Accountability and Democracy, Bernie Sanders Official Website, https:// berniesanders.com/issues/corporate-accountability-and-democracy/ (last visited Sept. 25, 2021).

${ }^{15}$ Robert H. Bates et al., Analytic Narratives (1999).

${ }^{16}$ Paul Pfleiderer, Chameleons: The Misuse of Theoretical Models in Finance and Economics, 87 ECONOMICA 81 (2020). 
pendency and hence a system's original position matters, the framework of analysis needs to be set out clearly.

Our analysis of the cyclicality of corporate governance proceeds as follows. In Section I, we explain in greater detail what we mean by the two influences in our binary account of the corporate governance system: capital market completeness, which is a key determinant of corporate ownership structure and provides the institutional foundation for a focus on shareholder value maximization; and policy channeling, which reflects the real government's instrumental use of corporate governance to advance non-shareholder interests.

In Section II, we trace cyclical shifts in U.S. corporate governance that reflect this endogenous cycle of how changes in the relationship between market completeness and policy channeling influence the structure of corporate governance. After a brief discussion of early conceptions of the corporation, we examine the mid-19th century shift in the United States from incorporation being possible only by a specific act of the legislature-typically only for a "public" purpose like infrastructure development-to "free" incorporation in which the corporate form became available to all without the government's normative review and regardless of the new entity's business. The shift is from the availability of the corporate form being driven by policy channeling to an increase in capital market completeness that expands the availability of equity financing to purely private ventures and private gains. Section II then takes up the cyclical reframing of Adolph Berle and Gardiner Means' classic 1932 account of the ownership distribution of U.S. public companies and that distribution's link to the structure of corporate governance. ${ }^{17}$ Continuing a focus on the distribution of ownership, Section II concludes by considering the enormous intermediation of U.S. equity ownership in the early 21 st century and the influence of concentrated equity ownership in institutional investors on the rise of activist investors.

Previously, we suggested that understanding the Hirschman-like cycles between market completeness and policy channeling makes context critical to understanding changes in corporate governance. In Section III, we turn to an account of the same cyclical pattern in other contexts. First, we survey the shift from the single-minded focus on policy channeling in the heyday of classic post-war Japanese corporate governance, to the slow but palpable recent shift in orbit toward shareholder value maximization over the past decade and, perhaps, the potential beginnings of movement back to policy channeling..$^{18} \mathrm{We}$ then examine the phenomenon of state ownership and in-

${ }^{17}$ Adolph A. Berle \& Gardiner C. Means, The Modern Corporation and Private Propertity (1932).

${ }^{18}$ See Kansai Econ. F., Developing Corporate Governance Structures to Improve MEDIUM- TO LONG-TERM CORPORATE VALUE (2019) (arguing against the core tenets of current shareholder-focused corporate governance reforms in favor of a return to longstanding Japa- 
fluence through the prism of Chinese corporate governance, an extreme form of stakeholder governance. Chinese corporate governance has undergone its own cyclical reframing process, in some respects surprisingly like the one we outline for Berle and Means. The Chinese context, however, presents a different relationship-complementary rather than competitive-between market completeness and policy channeling. In China, efforts to make the capital market more complete by creating the institutions needed to allow state-owned or influenced companies to raise funds from a public market have also served the policy-channeling goal of expanding Communist Party influence over corporate management. The presence of a pattern of shifting influences on corporate governance across both very different economic systems and over different time periods provides support for our explanation of the dynamics of corporate governance.

In Part IV we examine the principal channels through which disappointment with increased capital market discipline and the focus on shareholder wealth maximization has been directed in the U.S. and U.K., fueling the current shift in corporate governance reform efforts: the "stewardship movement" and the concept that corporations also should have a non-shareholder value "purpose." In both cases, the reforms would serve to moderate the effect of the capital market on corporate behavior to the end of giving corporate management more discretion. We explore the limitations of these channels to meet the expectations of reform proponents and argue that the inevitable disappointment eventually resulting from these efforts will set the stage for a shift back in the direction of shareholder wealth maximization. Recognizing the interaction between the binary influences on corporate governance and their Hirschman-esque cyclical character would help to make the current debate more transparent.

\section{The Binary Influences on Corporate Governance: Market Completeness and Policy Channeling}

\section{A. Market Completeness}

It is straightforward to show that ownership is at the center of the corporate governance solar system. A Copernican-like understanding of ownership follows straightforwardly from the fact that governance operates to facilitate risk transfer through the capital market. Stated simply, the capital market exists in important part to transfer risk, accomplished by the sale of financial interests in the corporation. The range of risk transfer instruments reflects the completeness of the capital market: in Arrow-Debreu terms, the extent to which there is a tradable instrument for every kind and slice of

nese stakeholder-oriented corporate governance practices). KEF is a Business Roundtable-like organization comprised of 1300 firms in the Kansai area, which includes such cities as Osaka, Kyoto, and Kobe, the second largest economic region in Japan. 
risk..$^{19}$ In turn, the corporate governance system exists in part to support that risk transfer-it allocates control among the holders of the risk transfer instruments that the corporation issues to reflect the instruments' relative incompleteness-in this sense, the reciprocal of market completeness.

For example, debtholders' participation in corporate decision-making is determined by the explicit provisions of the debt contract-the formal instrument the corporation issues with terms negotiated between the corporation and the debt provider. At the other end of the spectrum, common stockholders' participation is determined by the applicable corporate and regulatory law, which together with the corporation's organizational documents, comprise the equity contract. Debt governance is hard-edged: if interest is not paid or covenants breached, explicit remedies are set out in the underlying instrument, operating in the shadow of the bankruptcy regime.

Equity ownership, in contrast, is soft-edged: if dividends are not paid or corporate performance is less successful than expected, shareholders have recourse only to the corporate governance system-the ability to challenge the election of directors, the potential of a tender offer, and legal claims of breach of fiduciary duty by management. The range of available risk transfer instruments-the completeness of the capital market in Arrow-Debreu terms-thus dictates the instruments through which corporations choose to raise capital and, in turn, the structure of corporate governance that supports those instruments. With respect to equity securities, the control rights accorded common stockholders (and other instruments) by the instruments' designers allow the range of equity instruments made available through the capital market to slice risk, return, and control into a myriad of different equity instruments whose terms serve to influence the extent to which corporate management is protected from capital market influence. For example, an equity security that has the power to call a special shareholders meeting or to replace directors without cause is a different security than one whose holder lacks those powers. The ability to give shareholders those rights makes the capital market more complete, tailoring the character of influence associated with particular equity securities and its reciprocal, the exposure of management to capital market oversight. In this way, changes in the capital markets give rise to responsive changes in governance.

The result is that capital market completeness underpins shareholder control via the levers of corporate law and governance and emphasizes maximization of share value as the principal objective of the corporate governance system. As Leo Strine, Jr., then Chief Justice of the Delaware Supreme Court, put it, "[c]orporate power is corporate purpose." ${ }^{20}$

${ }^{19}$ See, e.g., Peter Friesen, The Arrow-Debreu Model Extended to Financial Markets, 47 ECONOMETRICA 689 (1979). Note that "completeness" in this context is not a normative term. Short of a fully complete capital market (a theoretical ideal type), there can be no general presumption that a more complete capital market is superior to a less complete one.

${ }^{20}$ Leo Strine, Jr., Corporate Power is Corporate Purpose I: Evidence from My Hometown, 33 Oxford Rev. ECON. POL'y 176 (2017). 


\section{B. Policy Channeling}

From the foregoing analysis, it follows that the goals of "corporate" (i.e., shareholder) governance and "real" governance (i.e., government's role in making distributional decisions and the use of corporate governance as an instrument of social change) are not necessarily the same and in fact may at times conflict. As we use the term in this essay, policy channeling means use of the tools of "real," as opposed to corporate, governance to influence what the corporation is charged with achieving and the design of a system that supports corporate pursuit of public policy objectives in addition to increasing the value of the securities issued by the firm. ${ }^{21}$ In the current corporate governance debate, non-shareholders benefiting from corporate action required or facilitated by regulation, or special protection like German co-determination requiring labor representation on the supervisory board, ${ }^{22}$ are termed "stakeholders," and the corresponding corporate governance system is termed "stakeholder governance." The beneficiaries of policy channeling efforts lie along a spectrum. At one end, a government may eschew the practice entirely, using direct regulation of corporate behavior solely with the objective of maximizing share value and mitigating any resulting externalities. This approach, which very loosely resembles the contemporary U.S. system in highly idealized form, assumes that social welfare is maximized by maximizing shareholder wealth at the firm level. This, of course, is Milton Friedman's (in)famous argument. ${ }^{23}$ The easiest way to see this is to imagine a corporate income statement. Every line on the income statement reflects a non-shareholder stakeholder, from revenues reflecting customer concerns, to cost of goods sold reflecting suppliers' role, to labor costs reflecting the corporate wage bill. ${ }^{24}$ In this Friedman-like framing, the input

${ }^{21}$ The term "policy channeling" was coined by Curtis Milhaupt and Mariana Pargendler to describe state ownership of business enterprises as a means of accomplishing policy objectives. Milhaupt \& Pargendler, supra note 2 . In this essay we use the term more broadly to describe a government's attempt (by whatever mechanism, including regulation, ownership or otherwise) to use the corporation as a means of advancing public policy objectives.

${ }^{22}$ Employee consultation and participation, codified in a variety of statutes, has a long history in Germany. Employee representation on the supervisory board of companies with more than 2000 employees is mandated by the Codetermination Act (Mitbestimmungsgesetz) of 1976. Gesetz über die Mitbestimmung der Arbeitnehmer [MitbestG] [Co-determination Act], May 8, 1976, Bundesgesetzblatt [BGBl] (Ger.), http://www.gesetze-im-internet.de/ mitbestg/index.html.

${ }^{23}$ Milton Friedman, The Social Responsibility of Business is to Increase Profits, N.Y. Times MAG., Sept. 13, 1970, at 17 ("there is one and only one social responsibility of business, to use its resources and engage in activities designed to increase its profits so long as it stays within the rules of the game, which is to say, engages in open and free competition without deception or fraud."). Like any brief account of a complicated matter, Friedman's statement begs most of the hard questions. For example, any corporate compliance system depends on the resources invested in the effort and the influences on that decision, such as the penalties for failure to comply. See Ronald J. Gilson, Corporate Governance versus Real Governance (Jan. 12, 2022) (unpublished working paper) (on file with the Harvard Business Law Review).

${ }^{24}$ Gilson, supra note 1 , at 24 . 
market for each line of the income statement drives the distribution of corporate performance among the various stakeholders.

At the opposite end of the spectrum, a government may pursue a strategy of state ownership of business corporations to achieve policy objectives through corporate governance elements wholly unrelated to, or even in conflict with, the goal of maximizing firm profits. For example, the state may resist privatizing financially underperforming businesses in order to maintain employment levels. In firms with mixed (state and non-state) ownership, the state may carry out public policy at the expense of non-state shareholders, who bear the cost of foregone profits in service of social or industrial policy goals. State ownership and influence thus represent an extreme form of "stakeholder governance," in which the state uses the corporate governance system instrumentally through its ownership to pursue considerations beyond shareholder wealth maximization. This policy channeling may influence not only decisions by corporate managers at the firm level, but also decisions of government agents overseeing the state's entire corporate portfolio. Contemporary China is the best illustration of this approach..$^{25}$

Between these two poles, we find governments using a variety of techniques to facilitate public policy goals through corporate governance. For example, the French government sought to encourage long-term shareholding, while magnifying its own influence as a shareholder in firms of strategic importance, by massaging corporate governance: it enacted a tenured voting system that provides double votes to shares held for at least two yearsmany of which are held by the state itself-thus leveraging government influence over corporate decisions. ${ }^{26}$

As we will discuss in more detail below, policy channeling is intertwined with the history of the corporation itself. A familiar example is the Dutch East India Company, which possessed quasi-governmental powers. Corporations in the early United States were required to serve a public purpose $^{27}$ and were widely considered to be "agencies of government. . for the furtherance of community purposes."28 In the pre-World War II period, Berle and Means envisioned that government action to accomplish broader purposes was necessary, some portion of which would take place indirectly through regulation of the corporate governance process and other portions through direct regulation of corporations' substantive activities. The most obvious example from this era is the proxy rules issued pursuant to the Se-

${ }^{25}$ Curtis J. Milhaupt, The State as Owner-China's Experience, 36 OXFORD REv. Econ. POL'y 362, 376 (2020). The Chinese approach is discussed more extensively infra Part III.

${ }^{26}$ Loi 2014-384 du 29 mars 2014 visant à reconquerir l'économie réelle [Law 2014-384 of Mar. 29, 2014 on Aiming at Reconquering the Real Economy], Journal. OfFICIEL DE LA Rf́publique Française [J.O.] [Official Gazelte of France], Apr. 1, 2014, p. 6231. See Curtis J. Milhaupt \& Mariana Pargendler, Governance Challenges of Listed State-Owned Enterprises Around the World, 50 CORNELl INT'L. L. J. 473, 485 (2017).

${ }^{27}$ Pauline Maier, The Revolutionary Origins of the American Corporation, 50 WM. \& MARY Q. 51,55 (1993).

${ }^{28} I d$. 
curities Exchange Act of $1934 . .^{29}$ In more recent examples, in 2018 California became the first U.S. state to mandate female representation on the boards of listed corporations headquartered there ${ }^{30}$ and in 2020 the first to mandate broad diversity representation on corporate boards. ${ }^{31}$ In Europe, Norway set a quota for female board representation more than a decade earlier than California, with dissolution a penalty for noncompliance. ${ }^{32}$

\section{Endogenous Shifts Between Capital Market Completeness and Policy Channeling}

In Hirschman's account of shifting involvements in individual and public affairs, disappointment is the mechanism driving the continuous shifts in individual preferences. In human behavior, disappointment is the emotion generated by a gap between expectations about personal consumption and public involvement, respectively, and the utility actually attained through those actions. In our account of commercial and organizational behavior, repeated oscillations in the relative weights of the two influences in corporate governance are driven in significant measure by disappointment with corporate performance. Corporate performance may fail to meet expectations due to excessive confidence in market mechanisms to provide the optimal mix of incentives and monitoring technologies for corporate managers to maximize shareholder returns, on the one hand, or overconfidence in the ability of corporations to provide solutions to broader social problems that ultimately require direct action by the government, on the other. Failure to meet unrealistic expectations in either realm of corporate governance or rising social or political dissatisfaction with the prevailing balance of influ-

${ }^{29} 15$ U.S.C. $\$ \$ 14(a), 78(n)$. Policy channeling is particularly evident in the SEC's regulation of shareholder proposals. See 17 C.F.R. $\$ 240.14 a-8$ (2021). The SEC recently extended its use of the proxy rules as a policy channeling device by adopting a regulation requiring the use of a universal proxy card that gives shareholders the ability to vote for their preferences among all candidates in a contested election rather than being effectively limited to voting for all nominees of a competing slate. See Universal Proxy, 86 Fed. Reg. 68.330 (Dec. 1, 2021) (to be codified as amended sections of 17 C.F.R. pt.240). The practitioner commentary generally treated the action as strengthening the hand of those undertaking proxy contests. See, e.g., K. Liekefett et. al., SEC Dramatically Changes the Rules for Proxy Contests, HARv. L. SCH. F. on CoRP. Governance (Nov. 19, 2021) https://corpgov.law.harvard.edu/2021/11/19/sec-dramatically-changes-the-rules-for-proxy-contests.

${ }^{30} 2018$ Cal. Stat. ch. 94 (codified as CAI. Corp. Code $\$ \$ 301.3,21115.5$ ). In signing the legislation, former California Governor Jerry Brown commented, "Given all the special privileges that corporations have enjoyed for so long, it's high time corporate boards include people who constitute more than half the 'persons' in America." Devika Krishna Kumar, California State Law Mandates Female Board Directors by 2019, Reuters (Oct. 1, 2018), https:// www.reuters.com/article/us-california-board-women/california-state-law-mandates-femaleboard-directors-by-2019-idUSKCN1MB172.

${ }^{31} 2020$ Cal. Stat. 92 (amending Cal. Corp. Code $\S 301.3$ and adding $\S 301.4$ and $\S 2115.6)$.

${ }^{32}$ Norwegian Public Limited Liability Companies Act, \$ 6-11a; see Aagoth Storvik, Women on Boards: Experience from the Norwegian Quota Reform, CESIFO DICE REP., Jan. 2011, at 35. 
ences, generates momentum, particularly following a scandal or crisis, toward a shift in the relative weights of the two influences in the opposite direction. As noted above and illustrated in the remainder of the essay, the specific actors and mechanisms involved in the effort to shift the balance of influences will vary over time and across different corporate governance systems.

\section{Cycles in U.S. Corporate Governance}

\section{A. From Legislative Chartering to General Incorporation Regimes}

Our account of the oscillation between the corporation as a vehicle for public policy and the corporation as a vehicle to enhance private interests in the corporation begins with early conceptions of corporateness and the eventual movement from government chartering to free incorporation regimes, followed in turn by renewed government intervention in corporate behavior in the form of regulation.

Early forms of legal personhood in ancient Rome and elsewhere were influenced by prevailing views on the ethics of commerce and suspicions of excessive wealth. As one commentator notes, "[t]hese overarching cultural norms may thus have contributed to a belief that incorporation was a privilege to be bestowed only on those endeavors that explicitly embodied a public purpose or social benefit to the exclusion of private commercial undertakings." 33

In the early modern period, a time of growing nation-state competition and imperial conquest, states began to grant corporate charters with appurtenant monopoly privileges as a means of advancing their global aspirations. ${ }^{34}$ Most famously, the Dutch East India Company was endowed with quasigovernmental powers, including the authority to wage war, create colonies, conclude treaties, and mint coins. The chartered companies in this era represented a "distinct break in [the corporation's] historical evolution since some privately-owned business pursuits could now be granted incorporation." 35 But the corporation nonetheless remained closely tethered to governmental functions. Monopoly privileges had to be justified by providing benefits to the nation-state that had granted them - whether in the form of increased trade, imperial conquest, or expansion of what today would be termed a country's soft power. ${ }^{36}$ Thus, "[h]istorically, corporations, like states, have been used to achieve ends of government." ${ }^{37}$

${ }^{33}$ Leonardo Davoudi et al., The Historical Role of the Corporation in Society, 6 J. BRIT. AC^D. 17, 24 (2018).

${ }^{34} \mathrm{Id}$. at $25-26$.

${ }^{35} \mathrm{Id}$. at 30 .

${ }^{36} \mathrm{Id}$.

37 Joshua Barkan, Corporate Sovereignty: Law and Government Under CapitalISM 5 (2013). The controversy over whether Huawei is an instrument of Chinese state strategy 
In the 19th century, governments throughout the world, regardless of political orientation, collaborated with private firms to provide public goods such as canals, railways, and docks. ${ }^{38}$ In a common approach, the government subsidized and guaranteed interest payments on bonds issued by the corporation that provided the public good. ${ }^{39}$ Consistent with the state's instrumental use of the award of corporate charters to facilitate public service activities, voting caps-which limited the number of shares any single shareholder could vote-were seen as preventing private control over the provision of public services. ${ }^{40}$ Sometimes failure of the private firm led to a takeover of the enterprise by the government, creating early examples of the state-owned enterprise ("SOE") 41 which we discuss in more detail below. These forms of state intervention in economic activity were widespread throughout the world prior to World War I. ${ }^{42}$ Similarly, in the pre-Civil War United States, corporate charters typically were granted by a special act of the state legislature for purposes deemed to be in the public interest. As has been noted, in this period "corporations were not exclusively profit-seeking associations but were quasi-public agencies of the state." 43

demonstrates that the issue remains current. See, e.g., Lindsay Maizland \& Andrew Chatzky, Huawei: China's Controversial Tech Giant, Councu. on Foreign Rels. (Feb. 12, 2020), https://www.cfr.org/backgrounder/huawei-chinas-controversial-tech-giant.

${ }^{38}$ Aldo Musacchio \& Francisco Flores-Macias, The Return of State-Owned Enterprises: Should We be Afraid?, HARv. INr'L Rev. (April 4, 2009), https://www.hbs.edu/faculty/Pages/ item. asp $\mathrm{x}$ ?num $=36235$.

${ }^{39}$ Id.

${ }^{40}$ See Henry Hansmann \& Mariana Pargendler, The Evolution of Shareholder Voting Rights: Separation of Ownership and Consumption, 123 YALE L.J. 948 (2014). Hansmann and Pargendier suggest that because shareholdings often were local, the voting caps operated, in effect, to support the corporation's role as a supplier cooperative serving the local merchants. See also Ronald J. Gilson, The Case Against Shark Repellant Amendments: Structural Limitations on the Enabling Concept, 34 STAN. L. Rrv. 775, 818 (1982) (arguing that voting caps were motivated by concern not for shareholders, "but for the community the corporation served."). Providence \& Worcester v. Baker, 378 A.2d 121 (Del. 1977), provides a contemporary account of the public function of voting caps in legislative chartering of infrastructure build-out. In the context of a bankruptcy proceeding, a railroad's largest shareholder challenged the voting cap formulas found in the railroad's charter that operated to reduce the complaining shareholder's vote from $28 \%$ to $3 \%$. As described in the Delaware Chancery Court's opinion, the cap was included in the corporation's 1844 Massachusetts legislative charter, which was required by an 1836 Massachusetts statute mandating voting caps on all railroad charters for the purpose of limiting "[c]oncentrations of control." E. Merrick DoDD, AMERICan Business Corporations Unte 1860: With Special Reference to Massachusetts 327-28 (1954).

${ }^{41}$ See Aldo Musacchio \& Sergio G. Laztarini, Reinventing State Capitailism: LeViathan In Businfss, Brazil. ANd Beyond 24 (2014).

${ }^{42}$ Musacchio \& Flores-Macias, supra note 38.

${ }^{43}$ David McBride, General Corporation Laws: History and Economics, $74 \mathrm{LAw} \&$ CONTEMP. Probs. 1, 3 (2011). Early Americans regarded corporations as "agencies of government," because the state authorized their individual creation to serve public purposes. Maier, supra note 27, at 55. For example, of the 317 legislative charters granted in the U.S. between 1780 and 1801, two-thirds were for transportation businesses. See JAMES WILLARD HuRST, The Legitimacy of the Business Corporation in the United States 1780-1970 17 (1970). Over the 70 years between 1790 and 1860, transportation companies represented onehalf or more of all corporations formed by number and authorized capitalization in all U.S. regions except for New England (due to New England's smaller size and therefore more lim- 
Nonetheless, extensive state involvement in the corporation came to be viewed with a certain unease in the United States. Government grants of privileges to entities with special prerogatives seemed anachronistic and troubling in the new republic. ${ }^{44}$ Concerns that corporations with special privileges were gaining too much power and crowding out private initiative began to grow, and with them a reaction to the corruption associated with legislative power to grant economically valuable special privileges to favored constituencies. ${ }^{45}$ Indeed, similar concerns had been voiced by Adam Smith, a staunch critic of chartered companies. ${ }^{46}$ The idea that incorporation should be available to all regardless of corporate purpose-free incorporation-began to take hold, particularly during the administration of Andrew Jackson. Starting in the mid-19th century, the states began to abolish special charters keyed to a quasi-public purpose and move to general incorporation regimes, in which the state provided charters to any corporation that met certain statutory requirements. By 1860, 24 of the 38 states and territories had enacted general corporation statutes, ${ }^{47}$ and the number of corporations formed under these statutes $(4,000)$ was gaining on those having legislative charters $(22,000){ }^{48}$

With the passage of time, introduction of a free incorporation regime and the resulting increase in capital market completeness had a major impact on the orientation of corporate law in the United States. Corporate law became "more liberal, removing restrictions on corporate size, duration, and activities, and moving toward the familiar enabling model of legislation." 49 By the late 19th century, the groundwork had been laid for state charter competition, whether to the top or to the bottom, a hallmark of the U.S. corporate law system. ${ }^{50}$

Over the later decades of the 19th century, the view of the corporation as serving a quasi-governmental function gradually gave way to a vision of the corporation as a private, profit-seeking organization well-suited to industrial activity. This shift in the role of incorporation from one focused on serving a public purpose to one available to all-a shift in the center of

ited transportation needs). See Richard Sylla \& Robert E. Wright, Corporation Formation in the Antebellum United States in Comparative Context, 55 Bus. HisT. 653, 656 (2013).

${ }^{44}$ See P.M. Vasudev, Corporate Law and Its Efficiency: A Review of History, 50 Ам. J. LEGAl Hist. 237, 253 (2010).

${ }^{45}$ See id. at 254.

${ }^{46}$ See Davoudi et al., supra note 33, at 31-32. See also Adam Smith, An Inquiry into the Nature and Causes or the Wealth of Nations 154 (1776).

${ }^{47}$ See Sylla \& Wright, supra note 43 , at 654.

${ }^{48}$ See Robert E. Wright \& Richard Sylla, Corporate Governance and Stockholder/Stakeholder Activism in the United States, 1790-1860: New Data and Perspectives, in ORIGINS of Shareholder AdVOCACY 231, 231 (Jonathan G.S. Koppel ed., 2011).

${ }^{49}$ Charles M. Yablon, The Historical Race; Competition for Corporate Charters and the Rise and Decline of New Jersey: 1880-1910, 32 J. CoRp. L. 323, 329 (2007).

${ }^{50}$ As the state charting system evolved, the outcome of competition appeared to result in a stable pattern of two winners: Delaware and the state in which a corporation had its principal operations. See Marcel Kahan \& Ehud Kamar, The Myth of State Competition in Corporate Law, 55 Stan. L. Rev. 679 (2002). 
gravity from the availability of the corporate form largely as a policy channeling tool to an increase in capital market completeness by making corporate stock broadly available as a private financing instrument-was reflected in an early 20th century assessment of the importance of free incorporation to economic growth:

Economic historians of the future may assign to the nameless inventors of limited liability, as applied to trading corporations, a place of honor with Watt and Stephenson, and other pioneers of the industrial revolution. The genius of these men produced the means by which man's command of natural resources has multiplied many times over; the limited liability company the means by which huge aggregations of capital required to give effect to their discoveries were collected, organized and efficiently administered. ${ }^{51}$

Corporate law came to focus increasingly on the governance rights of shareholders and the fiduciary duties directors owe to the shareholders. Thus, "the corporation had evolved from a specialized entity, created for the particular ends of the 'sovereign,' to an entity created to facilitate new and ever evolving forms of organization needed by the economy." 52 This view of corporate law would reach its zenith in the 1980 s, led by legal scholars Frank Easterbrook and Daniel Fischel, echoing Jensen and Meckling's seminal article, ${ }^{53}$ that characterized the corporation as a "nexus of contracts," and corporate law as a set of efficiency-enhancing default rules provided free of charge by the state. ${ }^{54}$

But privatization of the corporation, in this by now familiar account, gave rise to a new set of concerns. Corporate activity generates externalities whose costs are borne by society at large, pollution being the paradigmatic example, now replaced by climate change. In response to negative spillover effects from private commercial activity, the government reasserted itself, albeit indirectly, into the corporation through a host of federal laws regulating competition, worker safety, and pollution. The Sherman Antitrust Act of 1890, the Safety Appliance Act of 1893, and the Rivers and Harbors Act of 1899 are early examples. Thus, as one commentator notes, "state competition for charters can be viewed simultaneously as a success, insofar as it led

${ }^{51}$ The Ownership of British Industrial Capital, THF ECONOMIST, Dec. 18, 1926, at 1053. Functionally, limited liability was available long before free incorporation, arguably dating as far back as the Roman era. But there is no question that the development of the modern joint stock corporation facilitated a previously unavailable "off-the-rack" form of limited liability.

${ }^{52}$ McBride, supra note 43 , at 4.

${ }^{53}$ Michael C. Jensen \& William H. Meckling, Theory of the Firm: Managerial Behavior, Ownership and Agency Costs, 3 J. Fin. Econ. 305, 310-11 (1976).

${ }^{54}$ Frank Easterbrook \& Daniel R. Fischel, The Economic Structure of CorpoRATE LAW (1996). This characterization did not avoid vigorous empirical challenge. See Michael Klausner, Fact and Fiction in Corporate Law and Governance, $65 \mathrm{~S}_{\mathrm{TAN}}$. L. REv. 1325,1329 (2013). 
to a more efficient and coherent model of corporate law, and a failure in that it enabled corporate exploitation of negative externalities that required federal intervention." 55 Thus, the early history of corporate chartering in the United States through the end of the 19th century reveals Hirschman-esque shifts in public sentiment, in which the corporation is viewed first as a tool of government policy, then as a mechanism to facilitate private wealth creation, and finally as a direct object of government regulation.

\section{B. The Cyclical Reframing of Berle and Means}

A second pattern of oscillation between public and private concerns dominating corporate law and governance appears starkly from the changing academic understanding of Adolph Berle and Gardiners Means' iconic 1932 account of the distribution of shareholdings in public corporations and its corporate governance and policy implications. ${ }^{56}$ When viewed through a Hirschman interpretative lens, we see regular cycles in the framing of the relationship between shareholdings and governance, moving from policy channeling in response to the Great Depression to an understanding of the corporate governance structure as a means to facilitate capital market completeness, with its resulting focus on shareholder value.

1. Policy Channeling: This Hirschman-like public-private cycling begins with Berle and Means' 1932 revelation that the wide distribution of shareholdings in the very large corporations that they believed dominated the U.S. economy made it impossible for shareholders to effectively monitor managerial performance. ${ }^{57}$ The combination of widely distributed small shareholder ownership and large corporations drove the Berle and Means' conclusion that corporate governance could not constrain powerful managers: only the real government had the capacity to respond to the behavior of otherwise unconstrained managers of large corporations. ${ }^{58}$ Berle and Means thus built on the incapacity of shareholders to control the companies they owned to further a claim about the role of real governance, not the structure of corporate governance as that term came to be understood following its original appearance roughly contemporaneously with the first reframing of the Berle and Means thesis. If corporate governance could not police corpo-

55 Yablon, supra note 49 , at 329.

${ }^{56}$ Berle \& MFans, supra note 17.

${ }^{57}$ Stigler and Friedland point out that Berle and Means offered no empirical evidence of the actual effect of the separation of ownership and control. We take that fact as consistent with the operation of a softer Hirschman mechanism. See George J. Stigler \& Claire Friedland, The Literature of Economics: The Case of Berle and Means, 26 J. L. Econ. 237 (1983).

${ }^{58}$ Berle himself expressed an interesting, non-populist view of large business. Despite Berle's early employment by Louis Brandeis' law firm and an active role in the New Deal, Berle believed scale was economically important. Thus, he championed the government's role in policing the behavior of large businesses, rather than following Brandeis' view that very large businesses should be broken up. See Nicholas Lehman, Transaction Man: The Rise of the New Deal and the Decline of The American Dream (2019). 
rate behavior, then real governance was needed to protect the public interest, providing a justification for New Deal business regulation. Elaborating on this mechanism some decades later, Robert Clark explained that the government had to intervene to protect the public interest in the face of dispersed shareholders' "rational apathy" that flowed inexorably from the logic of free-riding and a corresponding lack of monitoring skills and incentives. ${ }^{59}$

2. Capital Market Completeness and Shareholder Governance: Now fast forward some forty years to 1976 and 1977, when academic understanding of Berle and Means' separation of ownership shifted sharply to the right, away from policy channeling and toward capital market completeness and shareholder value maximization. ${ }^{60}$ At this point, Berle and Means' New Deal-motivated account of the implications of widely distributed shareholdings was undercut by a new literature in economic history ${ }^{61}$ and financial economics. ${ }^{62}$ In remarkable fashion, this literature recast Berle and Means' account of how widely distributed stock ownership of very large companies was the problem to which New Deal policy channeling was directed, into a broader solution to a different set of problems. In the new account, the separation of ownership and management facilitated an efficiency-based solution: the intersection of the specialization of management that arose from managers no longer having to provide personal capital to an enterprise, and the specialization of risk bearing facilitated by shareholder diversification. Alfred Chandler, the leading business historian of his generation, summarized the reframing of the Berle and Means' problem as the product of this efficient dual specialization:

The rise of modern business management brought a new definition of the relationship between ownership and management. . . . Where the creation and growth of an enterprise required large sums of outside capital, the relationship between ownership and management differed. . . . Ownership became widely scattered. The stockholders did not have the influence, knowledge, experience, or commitment to take part in high command. Salaried managers determined long-term policy as well as managing short-term operating activities. They dominated top as well as lower and middle management. [For investors, the company became] a source of income not a business to be managed. ${ }^{63}$

${ }^{59}$ Robert C. Ci.Ark, Corporate Law 390-392 (2d ed. 1986). Clark was of course channeling Mancur Olson. See Mancur Olson, The Logic of Collective Action (1965).

${ }_{60}$ Stigler \& Friedland, supra note 57, express an early interest in what drives the dynamic in economic and political theory: "the process by which a proposition of great potential scientific and political significance gets established is fascinatingly mysterious." Id. at 237.

${ }^{61}$ Alfred D. Chandler Jr., The Visibi.e Hand: The Managerial Revolution in AMERICAN BuSiness (1977).

${ }^{62}$ See Jensen \& Meckling, supra note 53.

${ }^{63}$ Chandler, supra note 61 , at 9-10. 
To be sure, the agency costs resulting from the difficulty of small shareholders monitoring management had to be addressed, ${ }^{64}$ but this presented precisely the real-world frictions that markets and more limited disclosurebased government regulation could address. And this is where Jensen and Meckling, in their own way as impactful as Berle and Means' initial framing, entered the debate roughly contemporaneously and on the same side as Chandler. ${ }^{65}$ Hiring specialized managers meant giving the specialists the discretion to apply their expertise on behalf of shareholders. But that discretion also allowed the specialists to favor themselves at the expense of shareholders or, in Jensen and Meckling's terms, to impose "agency costs." These included both the costs of techniques to constrain management acting in its self-interest and the extent to which those constraints are nonetheless imperfect. Standard features of corporate governance, such as independent directors, disclosure requirements and audited financial statements, and capital market oversight, such as proxy fights and hostile takeovers, then could be understood as serving to reduce agency costs up to the point that additional efforts at constraints would cost more than the reduction in self-interested behavior. We see again a Hirschman-like shift: corporate governance became a tool to make the capital markets more complete by improving the efficiency of common stock as a financing vehicle.

The intellectual impact of Chandler's dual specialization narrative, and Jensen and Meckling's agency cost reframing of Berle and Means' populist account of the implications of ineffective small shareholders, is hard to overstate. For the next forty years the mission of American corporate law-and of corporate scholarship more broadly - took the form of a search for the organizational Holy Grail, a technique that minimizes the costs of efficient separation of ownership and control by aligning the interests of shareholders and managers, and so making the capital market more complete.

3. Shareholders as Owners: At this point, the concept of "ownership" evolved into something more instrumental. Shareholders were given exclusive voting rights not because they were in some conceptual sense "owners." Ownership had come to be widely understood as a bundle of rights. Which elements of the bundle a particular party is given depends on what the allocation is intended to accomplish. The inquiry is instrumental, not normative. This distinction, dating back at least to Hohfeld's 1913 formula-

${ }^{64}$ Chandler understood the specialization-imposed costs as a result of the unavoidable managerial discretion that accompanied the professionalization of management. His analysis paralleled Jensen's free-cash flow account of managerial overinvestment: "[I]n making administrative decisions, career managers preferred policies that favored the long-term stability and growth of their enterprises to those that maximized current profits. For salaried managers, the continued existence of their enterprise was essential to their lifetime careers." Id. at 10; see Michael C. Jensen, The Eclipse of the Public Corporation, HARv. Bus. Rrv., Sep.-Oct. 1989, at 61 (presenting the leveraged buyout organization as a more effective way of reducing the costs of specialization).

${ }^{65}$ The Jensen and Meckling article has been cited more than 100,000 times. 
tion $^{66}$ with respect to property rights generally, was reflected in the American Law Institute's 1936 Restatement of Property ${ }^{67}$ and was drawn sharply in the corporate governance context as early as 1981 . The shareholder's corporate governance role depends on the organizational design needed to give residual claimants the power to assess management and the board's performance-an instrument of agency cost reduction: "indeed, if the statute did not provide for shareholders we would have to invent them." 68

4. Reconcentration of Ownership: We now move forward another forty years or so from the initial reframing of Berle and Means' belief that the government had to intervene in corporate governance to serve a policy channeling purpose implemented through the New Deal, to a capital market completeness framing where governance served to minimize the agency costs of efficiency-driven separation of ownership and control, making common stock a more efficient financing technique. The second shift in the understanding of the separation of ownership and control took shape in the second decade of the 21 st century and was triggered by a fundamental change in the distribution of public corporation shareholders. Here we see a return to the increased completeness of the capital market and shareholder value maximization playing the leading role as opposed to Berle and Means' policy channeling account.

As late as 1950, Berle and Means' description of the ownership pattern they observed in the 1920 s remained accurate. Equities were still held predominately by households. In 1950, institutional investors, including pension funds, held only approximately $6.1 \%$ of U.S. equities. ${ }^{69}$ By 1980 , the distribution of shareholdings had begun to shift away from households toward institutions. At that time, institutional investors held $28.4 \%$ of U.S. equities. $^{70}$ By 2009 , the reconcentration of equity ownership through intermediation was largely complete: institutional investors held $50.6 \%$ of all U.S. public equities and $73 \%$ of the equity of the thousand largest U.S. corporations $;{ }^{71}$ by 2017 , total institutional holdings had risen to $70 \% .{ }^{72}$ At the same time, the emergence and stunning growth of index funds-passive as

${ }^{66}$ Wesley N. Hohfeld, Some Fundamental Legal Conceptions as Applied to Judicial Reasoning, 23 YAIE L.J. 16 (1913).

${ }^{67}$ Restatement (First) OF Propist $\$ \$ 8,10$ (Am. L. INST. 1936) (defining "real property" as one of a number of possessory interests and an "owner" as the holder of one of these interests).

${ }^{68}$ Ronald J. Gilson, A Structural Approach to Corporations: The Case Against Defensive Tactics in Tender Offers, 33 STAN. L. REv. 819, 834 (1981). Frank Easterbrook and Daniel Fischel made the same point in other publications. Frank H. Easterbrook \& Daniel R. Fischel, Voting in Corporate Law, 26 J. L. \& Econ. 395 (1983).

${ }^{69}$ Matteo Tonello \& Stephan Rahim Rabimov, The 2010 Institutional Investor Report 22, ThE Conf. BD., tbl.10 (2010); Ronald J. Gilson \& Jeffrey N. Gordon, The Agency Costs of Agency Capitalism: Activist Investors and the Revaluation of Governance Rights, 113 Col.um. L. REV 863, 874 (2013).

${ }^{70} I d$.

${ }^{71}$ Id. For a time series of institutional ownership between 1950 and 2004, see Jeffrey N. Gordon, The Rise of Independent Directors in the United States, 1950-2005: Of Shareholder Value and Stock Market Prices, 59 STAN. L. Rev. 1465, 1568 (2007). 
opposed to active asset management-resulted in the concentration of institutional owners. By 2016, the largest 20 institutions controlled on average some $33 \%$ in each of the 20 largest corporations..$^{73}$ By 2018 , the intermediation of equity and the shift from active to passive management was complete. Between 2009 and 2018, the percentage of U.S. equity funds managed passively increased from $19 \%$ to $44 \%$. Because of the huge scale economies associated with passive management, the market became highly concentrated: the three largest passive managers-BlackRock, Vanguard, and State Street-in 2017 held over $15 \%$ of the S\&P 500.74

This intermediation of equity - holdings of common stock shifting from direct individual ownership to individual beneficial ownership held through record intermediaries like mutual funds and pension funds and the concentration of institutional ownership-had turned Berle and Means' empirical observation of ownership on its head. Rather than shareholdings of U.S. corporations being widely distributed as Berle and Means had reported some eighty years earlier, the combination of modern finance theory favoring diversification, the post-World War II U.S. policy decision that savings for retirement would be channeled through corporate pension plans rather than a broad expansion of Social Security and, finally, the shift from defined benefit to defined contribution retirement plans, resulted in an enormous concentration of corporate record ownership, what Gilson and Gordon referred to as "agency capitalism." 75 Put figuratively, representatives of institutions that collectively maintained effective control of most large U.S. corporations without a controlling shareholder could fit around a boardroom table. For example, Vanguard, BlackRock, and State Street, the three largest index fund providers, in 2017 held in the aggregate approximately $15 \%$ of the outstanding shares in the S\&P 500; some $31 \%$ of S\&P 500 companies have four or fewer shareholders that collectively hold more than $20 \%$ of the companies' outstanding stock. With respect to Apple, which often has the highest market capitalization of any public stock, the index troika held $20 \%$ of the outstanding stock. ${ }^{76}$

This shift in ownership then gave rise to a new governance structure. Activist investors, largely in the form of hedge funds, took advantage of the reconcentration of equity by using the proxy process to present strategic al-

${ }^{72}$ Eric Posner, Fiona Scott Morton \& E. Glenn Weyel, A Proposal to Limit the Anticompetitive Power of Institutional Investors, 81 ANTitrust L. J. 669 (2017).

${ }^{73}$ See Lucian A. Bebchuk, Alma Cohen \& Scott Hirst, The Agency Problems of Institutional Investors, 31 J. ECON. PersP. 89, 92 (2017); Ronald J. Gilson \& Jeffrey N. Gordon, Agency Capitalism: Further Implications of Equity Intermediation, in RESEARCH HANDBOOK on Shareholder Power 32, 35 (Jennifer G. Hill \& Randall S. Thomas eds. 2015).

${ }^{74}$ See John C. Coates, The Future of Corporate Governance Part I: The Problem of Twelve (Harv. L. Sch., Pub. L. Working Paper, Paper No. 19-07, 2018), https://ssrn.com/ abstract $=3247337$.

${ }^{75}$ Gilson \& Gordon, supra note 73.

${ }^{76}$ See Coates, supra note 74 . Gilson \& Gordon, supra note 73 , trace the forces that drove this intermediation of equity. 
ternatives to institutional owners of corporations which the activists believe to be underperforming. If corporate management does not agree to adopt the proffered strategies, the activist then runs (or threatens) a proxy fight to replace some or all of the existing board with a slate selected by the activist. Large institutional shareholders have the resources and expertise to assess the activist's proposal and typically hold sufficient stock collectively to influence the activist's likelihood of winning the strategy-motivated proxy fight. Institutional investors thus came to play the role Berle and Means claimed that the widely distributed shareholders in 1932 could not: effectively monitoring the performance of management, but now through the mechanism of activist intermediaries.

The extent of this change in the capacity of a more complete capital market to monitor management cannot be overstated. Hostile takeovers in the 1980 s operated by leveraging the assets of targets to support the borrowing necessary to fund the takeover. The largest companies, however, were protected from hostile bids by the capital market's inability to fund takeovers at this scale. ${ }^{77} 21$ st century activist proxy challenges are quite different and potentially far more powerful; activists leverage the institutional investors' stock ownership and hence their votes, rather than leveraging the target's balance sheets in order to buy the target. In most cases, the activist does not have to win the proxy contest in order to be successful: an increasing percentage of proxy contests over the past twenty years have resulted in a settlement with incumbents in which the activist obtains board seats. ${ }^{78}$ The institutions own roughly the same percentage of large public corporations as smaller ones, with the result that no company without a controlling shareholder is large enough to be protected from an activist challenge by size alone. ${ }^{79}$

The threat to managements of even the largest corporations gave rise to the final and most radical reframing of Berle and Means: a shift back toward policy channeling in response to the impact of a greater emphasis on shareholder value maximization facilitated by a more complete capital market. Management and their supporters disparage shareholders' efforts to maxi-

\footnotetext{
77 The growing completeness of the capital market during the period of hostile takeovers did cause much larger companies to become plausible targets. The standard account of this broadening of the size of possible takeover targets dates to KKR's ability quickly to raise the debt necessary to fund its 1988 acquisition of RJR Nabisco. BRYAN BURROUGH \& JOHN Helyar, BARBARIANS AT THE GATE (1989).

${ }^{78}$ From 2001 to 2016 , the percentage of proxy contexts ending in a settlement in which the activist obtains a board seat increased from less than $25 \%$ to almost $50 \%$. Jason Frankl \& Steven Balet, The Rise of Settled Proxy Fights, Harv. L. Sch. F. ON Corp. Governance (March 22, 2017), https://corpgov.law.harvard.edu/2017/03/22/the-rise-of-settled-proxyfights/.

${ }^{79}$ From 2016 through 2019 , an average of sixty-six companies were targeted for proxy contests, resulting in an average of 133 board seats won per year. In approximately $84 \%$ of the cases, the seats were obtained through settlement. Lazard S' holder Advisory Grp., Lazard 2019 Shareholder Activism Review 15, tbl. 4 (2019) https://www.lazard.com/perspective/lazards2019-annual-review-of-shareholder-activism/.
} 
mize share value, made possible by the concentrated intermediation of equity and animated by activist hedge funds. They portray such efforts as forcing managers to manage in the short run, to the detriment of the long-run best interests of the corporation, the shareholders, and the economy. ${ }^{80}$ Recall that Berle and Means defined the problem posed by widely held small shareholders as managers being unconstrained by shareholders, which required real government intervention for the benefit of the entire economy, rather than to maximize shareholder value. When the intermediation of equity imposed the missing shareholder constraint some eighty years later, management supporters then argued that managerial autonomy-precisely the circumstance that gave rise to Berle and Means' concern-was the solution, not the problem. Shareholder value maximization, now turbocharged by concentrated equity intermediation and the resulting agency capitalism, thus gave rise to yet another, corresponding Hirschman-like shift: the push back against shareholder primacy, now said to result in short-termism, reduced innovation, and increased income equality. We analyze the channels through which the current shift in the direction of stakeholder-orientated capitalism is being directed in Part IV.

\section{Summary}

Our sketch of key moves in the intellectual and legal development of U.S. corporate governance over the past two centuries reveals a distinct pattern of oscillation between two very different views of the corporation-as an instrument of public policy for the government and as a tool of private wealth creation for investors. These periodic shifts in the prevailing conception of the corporation are in significant respects endogenous, a product of disappointment with the social or economic effects of the then-prevailing balance of influences in corporate governance.

\section{Governance Cycles Outside the U.S.}

To this point, our analysis of Hirschman-like cycles of shifting influences on corporate governance has focused on the United States. We now extend our analysis to governance cycles in other parts of the world. We focus initially on Japan because it demonstrates that, at any given time, the emphasis of different countries' governance systems may be at different points in the cycle between policy channeling and capital market completeness. Put in spatial terms, a snapshot of a country's corporate governance system typically will reflect an interior, rather than a corner solution, with

${ }^{80}$ Compare Lynn A. Stout, The Toxic Effects of Shareholder Primacy, 161 U. PA. L. REv. 2003 (2013), with Mark J. Roe \& Roy Shapira, The Power of the Narrative in Corporate Lawmaking (Eur. Corp. Governance Inst., Working Paper No. 554, 2020), https://ssrn.com/ abstract $=3703882$. 
the system located at a point along a continuum, with one endpoint marking pure policy channeling and the other pure capital market completeness. As we will see, Japanese corporate governance has been shifting, fitfully to be sure, away from policy channeling and stakeholder concerns, toward capital market completeness and a greater emphasis on shareholder wealth maximization. This heightened focus on the corporation as a tool of shareholder wealth creation has occurred over a period when the U.S. and the U.K. were moving in the opposite direction, toward stakeholder-oriented policy channeling. The fact that different systems of corporate governance can simultaneously be moving in opposite directions along the continuum is a reminder of the importance of context in comparative analysis and a cautionary tale about the barriers to global convergence toward a particular ideology or ideal type of corporate governance. Important to our analysis here, the observation of similar shifts in influence in countries with different histories and at different times supports our general claim: that shifts between efforts at greater capital market completeness and efforts at policy channeling are inherent in corporate governance systems.

We then take up Chinese corporate governance, situating it first within the longer history of state ownership, in its own way revealing a cyclical pattern favoring and disfavoring this most direct mechanism of policy channeling. The Chinese system is especially interesting because the country's economic ascendance paradoxically coincides with its heavy reliance on state ownership and control of business enterprise, the most extreme form of policy channeling and stakeholder focus. But as we will explain, the distinctive form of Chinese policy channeling has been facilitated by increasing capital market completeness, turning the continuum three-dimensional.

Our ambition is not to provide exhaustive accounts of the Japanese and Chinese systems, but to underscore that the endogenously driven cycles in corporate development are not linked to a particular country, a particular system of economic organization or ideology, or a particular point in time. In our account, the corporate governance systems of the U.S. and Japan are at this time moving in opposite directions along the continuum overly roughly the same period, and China, while distinctive in some respects given the overtly political elements of its corporate governance system, has also exhibited the pattern of oscillation in its relatively brief era of market-oriented reform.

\section{A. Japan: From Policy Channeling to Shareholder Capitalism}

We described in Part $\Pi$ how changes in the understanding, and actual distribution, of share ownership in U.S. public corporations reflected a pattern of shifts between the role of policy channeling and capital market completeness over the period from 1932 through the present. Here we highlight a very different shift in governance direction in a different part of the world, in the opposite direction from that of the U.S.: away from explicit use of corpo- 
rate governance for policy channeling purposes, and toward capital market completeness via political economy changes that placed greater emphasis on shareholder value and, ultimately, a more explicitly shareholder wealth maximization role for the corporation in society. In the Japanese case, the key mechanisms driving the shift in orientation are explicit government policy ("Abenomics") and the rise of foreign institutional investors in the Japanese capital market.

During Japan's high-growth era, corporate governance-structured around informal institutions developed in the post-war period-served to support fundamental social objectives, including most importantly stable long-term employment. This was a significant departure from pre-war Japanese corporate governance, in which "[s]hareholders were the kings of the system." $"$ The post-war commitment of large firms to lifetime employment for a significant portion of the labor force resulted in a bank-centered, as opposed to capital market-centered, system of corporate finance, because the former was less likely to upset a company's implicit commitment to labor. A company's "main bank" (its largest lender, which typically also held equity in the borrower) monitored its performance and was expected to assist the company in the event of financial distress. Stable shareholding networks among affiliated firms with the same main bank (the keiretsu system) further insulated managers from capital market pressures, creating the leeway needed to support a long-term investment in human capital. Japan's banking system, in turn, was backstopped by an implicit "no failure" guarantee from the government. ${ }^{82}$ The interaction of these informal institutions supported corporate management's implicit promise of lifetime employment for a major portion of the (male) labor force ${ }^{83}$ In this way, the institutions of corporate governance supplied important elements of Japan's post-war social safety net. Standard features of a capital market or shareholder-centric system, such as hostile takeovers and proxy contests, activist investors, and managerial focus on financial returns, were not prevalent in this system, and

${ }^{81}$ See Takeo Hoshi \& Anil Kashyap, Corporate Financing and Governance in JaPAN: The Road to THE Future 50 (2001) ("Overall, the pre-war system seems to be an era when the banks. . .stayed out of the corporate governance process. Rather, the shareholders seemed to have taken the lead in monitoring firms and hectoring management. The pre-war financial system can be summarized as one in which securities markets were largely dominant. Banks were profitable and provided a significant amount of financing, but equity and bond financing were more important. Shareholders were the kings of the system. In fact, if one compares the pre-war system to the post-war U.S. system and post-war Japanese system, the U.S. system has more in common with pre-war Japan.").

${ }^{82}$ See Curtis J. Milhaupt \& Geoffrey P. Miller, Conflict, Cooperation and Convergence: Evidence from the "Jusen" Problem, 29 LAw \& Pol.'Y INT'L Bus. 1, 48 (1997) (analyzing the operation of informal norms, including the "no-failure norm," in Japanese banking through the early 90 s).

${ }^{83}$ See Curtis J. Milhaupt, Creative Norm Destruction: The Evolution of Nonlegal Rules in Japanese Corporate Governance, 149 U. PA. L. REv. 2083 (2001); Ronald J. Gilson \& Mark J. Roe, Lifetime Employment: Labor Peace and the Evolution of Japanese Corporate Governance, 99 Colum. L. Rev. 508 (1999). 
were often denigrated as anathema to Japan's version of corporate capitalism. ${ }^{84}$

The bursting of Japan's asset bubble and ensuing financial crisis at the outset of the 1990s seriously weakened the institutions of post-war corporate governance. The "lost decade" saw persistent low growth and low or negative inflation. ${ }^{85}$ Banks failed and some weak banks were merged. Main bank and stable shareholding relationships began to unwind, ${ }^{86}$ eroding keiretsu corporate group identity, which had been centered around the main bank system. Managerial practices rooted in the post-war period, which placed heavy emphasis on maintaining market share and protecting employees, became excessively risk averse and poorly attuned to efficient use of capital in light of changes in business conditions. The innovative capacity of the Japanese economy declined. ${ }^{87}$ Firms reacted to the deflationary environment by growing more reluctant to hire workers protected by lifetime employment, leading to a major increase in the percentage of "non-regular" workers with lower pay and less job security. ${ }^{88}$ Japan's post-war social safety net began to fray along with its system of corporate governance.

The weakening of post-war, bank-centered corporate governance institutions created a disciplinary void for Japanese managers. In 2014, The Economist decried the "lack of supervision of top Japanese management [, which] contributes to chronic underperformance." 89 In the wake of the Olympus accounting scandal, The Economist asked, "[w]ant to invest in underperforming companies with no outside directors? Go to Japan." 90 In a working paper with Alicia Ogawa, Ken Hokugo, the director of corporate

${ }^{84}$ See id. at 2089. In 2008, an official from one of Japan's most powerful ministries gave a speech in which he questioned the notion that Japanese companies needed to change in response to changes in the global economy. He made the case that companies should be able to choose their shareholders (which he described as "fickle, irresponsible, and greedy") rather than the other way around. Michiyo Nakamoto, One Way Street? As Its Companies Expand Abroad, Japan Erects New Barriers at Home, Fin. Times (Mar. 2, 2008), https://www.ft.com/ content/98c40880-e858-11dc-913a-0000779fd2ac.

${ }^{85}$ Japan's Pre-1990 GDP growth rate resulted in GDP doubling every 14 years. The post1990 growth rate implies a doubling of GDP every eighty years. Fed. Rsrv. Bank of St. Louis, Japan's Lost Decade vs. the U.S. Great Recession, ON THE Econ. (June 25, 2018), https:// www.stlouisfed.org/on-the-economy/2018/june/japan-lost-decade-us-great-recession.

${ }^{86}$ See Hideacki Miyajima \& Fumiaki Kuroki, The Unwinding of Cross-Shareholdings in Japan: Causes, Effects, and Implications, in Corporate Governance IN JAPAN: Institu. tional Change and Organizational Diversity 79 (Masahiko Aoki, Gregory Jackson \& Hideaki Miyajima eds., 2007).

${ }^{87}$ See Lee G. Branstetter \& Yoshiaki Nakamura, Is Japan's Innovative Capacity in Decline?, in Structural Impediments to Growth in Japan 191 (Magnus Blomström et al. eds. 2003).

${ }^{88}$ Andrew Gordon, New and Enduring Dual Structures of Employment in Japan: The Rise of Non-Regular Labor, 1980s-2010s, 20 SOC. SCI. JAPAN J. 9, 9 (2017) (reporting rise in nonregular employees as percentage of total from $15 \%$ in 1982 to $38 \%$ in 2014).

${ }^{89}$ Corporate Governance in Japan: A Revolution in the Making. ECONOMIST (May 3, 2014), https://econ.st/2XOXODD.

${ }_{90}$ Corporate Governance in Japan: Olympian Depths, The EConomist (Nov. 3, 2012), https://econ.st/3CEbwrw. 
governance for Japan's Pension Fund Association, summed up the situation circa the second decade of the 21 st century as follows:

Japanese companies have long been less profitable than their global peers; they have lost global market share; they have chosen to accumulate huge cash balances rather than taking risk to spur innovation. They have been very resistant to transparency with outsiders (particularly shareholders), which has given rise to some recent examples of malfeasance. ... A large percentage of publicly-listed Japanese companies still trades at less than book value, indicative of investors' assumption that management is not capable of creating new growth. ${ }^{91}$

A variety of background factors added to the growing sense of urgency around corporate governance reform. A mature economy with a rapidly ageing and declining population must generate returns on assets to meet pension obligations and prevent further expansion of deficits. ${ }^{92}$ Shrinking domestic markets compel managers to seek new opportunities for innovation and new investments abroad. Changes in the ownership structure of Japanese listed companies over the past two decades, particularly a significant increase in the percentage of shares held by foreign investors, ${ }^{93}$ began to expose Japanese managers to heightened levels of investor expectations and engagement.

Against this backdrop, the second Shinzo Abe government (2012-2020), devised a "revitalization strategy" which included a series of corporate governance reforms explicitly designed to invigorate the economy by encouraging risk taking and a focus on financial returns-a pronounced shift toward shareholder focus. A Stewardship Code was adopted in 2014 in the hopes of invigorating arms' length institutional investor engagement with portfolio firms in support of the Abe push toward performance. As we will see in Part IV, this motivation for the Japanese Stewardship Code's adoption contrasts with the situation in the U.K. and the U.S., where institutional investor engagement has been encouraged to provide management a buffer

${ }^{91}$ Ken Hokugo \& Alicia Ogawa, The Unfinished Business of Japan's Stewardship Code (Ctr. for Japanese Econ. \& Bus.: Corp. Governance \& Stewardship Program, Working Paper No. 1, 2017), https://academiccommons.columbia.edu/doi/10.7916/D8D79PTM.

${ }^{92}$ As an influential report for Japan's Ministry of Economy, Trade and Industry puts it, "Japan must transform itself into an 'asset management nation' focused on deriving returns from long-term investments." Kunio Ito, Ito Review of Competitiveness and INCEN'TIVES for Sustainable Growth: Bumling Favorable Relationships Between Companies and INVESTORS 3 (2014), https://www.meti.go.jp/english/policy/economy/corporate_governance/ pdf/FRIR.pdf.

${ }^{93}$ The percentage of shares held by foreigners (virtually all institutions) rose from approximately 5\% from 1970-1985 to about $30 \%$ in 2018. JAPAN Exch. GrP., INC., 2018 SHARE OWNERSHIP SURVEY, 4 tbl. 3 (2019), https://www.jpx.co.jp/english/markets/statistics-equities/ examination/b5b4pj000002xzt8-att/e-bunpu2018.pdf 
from capital market pressure. ${ }^{94}$ Japan's Companies Act was amended effective in 2015 to provide a new option for corporate board structure focused on improving the board's audit and supervision function. A Corporate Governance Code was adopted on a comply or explain basis that same year to encourage the appointment of independent directors and to compel disclosure of the rationale for stable (read: quiescent) shareholding practices, in the expectation that this obligation would cause further unwinding of crossshareholdings. The Corporate Governance Code seeks "growth-oriented governance." 95 It "does not place excessive emphasis on avoiding and limiting risk or the prevention of corporate scandals. Rather, its primary purpose is to stimulate healthy corporate entrepreneurship, support sustainable corporate growth, and increase corporate value over the mid- to long-term." 96

The ambition reflected in these reforms should not be lost in their anodyne garb. It is no exaggeration to say that the Abe reforms sought a fundamental reorientation of post-war Japanese corporate governance toward the capital markets and a significant elevation of the shareholder in the pecking order of stakeholders. Thus, Abe's reforms "represent more than tinkering with the formal relationships between shareholders and managers . . . . [They] reflect a conscious effort to use government intervention to overcome path dependencies that sustain a no longer advantageous system of governance and production." ${ }^{97}$ More colloquially, the new approach could be labeled "Show Me the Money Corporate Governance."

Predictably, the results of these interventions to date have been mixed. Moving the Japanese economy toward shareholder-centric capitalism founded on more complete capital markets is no small feat: for many firms, the emphasis on accountability to the capital market, channeled in part through independent directors representing the interests of investors, is an imperfect fit with Japan's post-war stakeholder-oriented organizational struc-

${ }^{94}$ The Japanese Stewardship Code was modeled on the U.K. Stewardship Code, but its purpose is quite different: to encourage institutional investors to "enhance the medium- to long-term investment return for their clients and beneficiaries . . . by improving and fostering the investee companies' corporate value and sustainable growth through constructive engagement, or purposeful dialogue, based on in-depth knowledge of the companies and their business environment." Gen Goto, The Logic and Limits of Stewardship Codes: The Case of Japan, 15 Berkel.ey Bus. L.J. 365, 371 (2019) (quoting The Councr or Experts Concerning the Japanese Version of the STewardship Code, Principles for Responsibie Institutional. Investors $<<$ Japan's Stewardship Code $>>$ : To Promote Sustainable Growth of Compantes Through Investment And Dinlogue 1 (2014), https:// www.fsa.go.jp/en/refer/councils/stewardship/20140407/01.pdf); see also infra Part IV.

${ }^{95}$ The Council of Experts Concerning the Corp. Governance Code, The Preamble of "Japan's Corporate Governance Code [Final Proposal]" I 7 (2015) (internal quotation marks omitted), reprinted in Tokyo Stock Exch., Inc., Japan's Corporate Governance Code app. (2021), https://www.jpx.co.jp/english/equities/listing/cg/tvdivq0000008jdy-att/b5b4pj 0000046 p7l.pdf.

${ }^{96} \mathrm{Id}$.

${ }^{97}$ Gilson, supra note 1 , at 12.

${ }^{98}$ John Vail, Japan's "Show Me the Money" Corporate Governance: $4 Q$ Economic Troubles, ForBis (March 4, 2019), https://www.forbes.com/sites/johnfvail/2019/03/04/japansshow-me-the-money-corporate-governance-4q-economic-troubles/\#6e459ad82b7d. 
tures and practices, particularly in the realm of employment. ${ }^{99}$ Moreover, there is no emergent social consensus around the benefits of shareholder wealth maximization to smooth the transition. And there are limits to what soft law codes and new board structure options can accomplish, particularly in the face of resistance from important segments of the corporate sector. In short, there is an unresolved tension in Japan between the aspirations reflected in the Abe corporate governance reforms and the sticky logic of the institutions of post-war Japanese capitalism. The stickiness is in plain view in the statement of the Japanese regional business lobby we highlighted in the Introduction. The statement warns against "obsess[ion] with shareholders in pursuit of maximization of shareholders' benefits above all other stakeholders' interest." 100 It stresses instead the "universal value" of Japanese management philosophies:

These philosophies stress the bonds that companies have with all stakeholders, including shareholders, employees, customers, business partners, local communities, and other parties besides institutional investors, and they represent a set of values that insist that corporate value can be continuously boosted by sharing the fruits of corporate activities with this broad range of stakeholders. ${ }^{101}$

The Abenomics reforms might be viewed simply as an example of attempted policy channeling in response to a crisis. Like Elizabeth Warren's proposed Accountable Capitalism Act in the United States, ${ }^{102}$ the Japanese reforms represent an attempt to fundamentally alter the country's system of capitalism in the wake of its perceived failures. But the Abenomics reforms are distinctive as an example of policy channeling that encourages a Hirschman-esque shift toward increased capital market completeness and thus greater attention to corporate profitability and risk taking in the interests of society as a whole, where the U.S., and the typical policy channeling shift, is in the other direction. Contrasting the U.S. and Japanese responses thus illustrates the critical importance of context in corporate governance reform: In Japan, rising disappointment with the financial performance of a governance system driven by excessive attention to stakeholder (particularly employee) interests despite changing economic conditions prompted government interventions to enhance shareholder governance and capital market discipline: a shift toward capital market completeness. If ultimately successful, these interventions would return Japanese capitalism to its more capital market-oriented pre-war incarnation.

${ }^{99}$ See Masahiko Aoki, Toward an Economic Model of the Japanese Firm, 28 J. Econ. LiT. 1 (1990).

${ }^{100}$ Kansai Econ. F., supra note 18, at 1-12.

${ }^{101}$ Id. at 2 (emphasis in the original).

${ }^{102}$ Accountable Capitalism Act, S. 3348, 115th Cong. (2018). 


\section{B. China: State Ownership and Policy Channeling}

We turn now to a more recent East Asian high growth economy, one that has attained a remarkable track record of growth under (or perhaps despite) a system of state ownership and pervasive political influence on corporate governance-China. We begin with a short account of the history of the SOE, both to provide context for the China discussion and because this history reflects its own, Hirschman-esque pattern over the course of nearly two centuries: the rise, fall, and resurrection of the SOE.

Attitudes toward the SOE as a form of business organization have undergone a cyclical process of reframing over the past century and a half ${ }^{103}$ with loose parallels to the one we described in Part II for the Berle-Means corporation. Economic theory has traditionally explained the SOE as a response to natural monopolies or as a means of providing public goods such as canals, railroads, and mail service-straightforward examples of policy channeling parallel to that seen in the early U.S., largely limiting state chartered corporations to infrastructure related enterprises. ${ }^{104}$ In these settings and subject to various assumptions, government agents maximizing social welfare can be expected to make more optimal decisions in running a firm than private profit-maximizing managers. ${ }^{105}$

SOEs developed in the 19th century to provide public goods of the sort mentioned above. In a common arrangement, a government would partner with a private actor to build and operate a facility providing the public good. Often the government ended up owning the public good provider after the failure of the private firm to which the concession had been granted. ${ }^{106}$ Many nationalizations of business enterprise in the first half of the twentieth century are best understood as government bailouts of failing corporations to insure the continued supply of public goods. ${ }^{107}$

Nationalizations of private industry reached their apex in the aftermath of World War II. A wave of nationalizations took place in Western Europe to rebuild devastated wartime economies. Nationalizations also were prevalent in post-war shifts toward socialist economic strategies as in India following its 1947 independence. In many developing countries, import substitution policies relied upon SOEs to nurture industries where start-up costs exceeded the private sector's funding capacity. State-owned banks were often used to provide the funding for these infant industries. SOEs were of course

${ }^{103}$ The historical survey of the SOE draws on Curtis J. Milhaupt, The State as OwnerChina's Experience, 36 OXFORd Rev. ECON. POL'Y 362, 363 (2020).

${ }^{104}$ See supra text at notes 33-37.

${ }^{105}$ See Talis J. Putnins, The Economics of State-Owned Enterprises, 38 Int'L J. Pub. Admin. (2015); see also Anthony B. Atkinson \& Josfiph E. Stigititz, Lectures on Public ECONOMICS 457-81 (1980). In this regard, treatment of early U.S. state chartered local infrastructure projects as, in effect, local cooperatives, represents a work-around over pure public ownership. See Hansmann \& Pargendler, supra note 40, at 948.

${ }^{106}$ MusACChIo \& Lazzarini, supra note 41 , at 23-24.

${ }^{107} \mathrm{Id}$ 
ubiquitous in the non-capitalist world as well, where state ownership of the means of production was a central facet of political ideology.

By the 1980s, however, the tide of sentiment had shifted against the SOE as a strategy through which to carry out government policy intervention in the economy. Insulated from competition and subject to the whims of their overseers in government, SOEs gave rise to disappointment grounded in their reputation for inefficiency, waste, clientelism, and corruption, and became a serious burden on the public finances of many countries. The costs associated with government ownership came to be viewed as heavily outweighing the public benefits. ${ }^{108}$ Agency theory provided an explanation for the real-world departure from the theoretical ideal: SOEs are ostensibly owned and operated in the public interest, but citizens and the political process are generally powerless to monitor and discipline the government agents and SOE managers actually running these firms, which lends itself to broad-based corruption. Lacking any true principals and in the absence of capital market or public discipline, the SOE came to be viewed as a black box of agency problems, including especially rampant government corruption. Brazil's spasm of political corruption surrounding state oil company Petrobras in the Lava Jato scandal, which led to the impeachment of President Dilma Rouseff, is a vivid contemporary example of these ills. ${ }^{109}$

Margaret Thatcher famously embarked on an aggressive plan of privatizing the UK's post-war nationalizations under the banner of increased efficiency and smaller government. By 1987, the Thatcher government had sold more than $\$ 20$ billion in state assets, including British Airways and British Telecom. ${ }^{110}$ The disappointment with the results of post-war nationalizations gave rise to a wave of privatizations from New Zealand to the African continent, and from the Philippines to Brazil. By the end of the 1980s, the proceeds from sales of SOEs worldwide reached $\$ 185$ billion. ${ }^{111}$ When the Berlin Wall fell at the end of the decade, privatization campaigns swept over Russia and Eastern Europe. The death of the SOE appeared imminent.

Fast forward now to the twenty-first century. Not only has the SOE survived in the ecology of business organizations, it has proliferated and evolved into a major player in the global economy. As of the end of 2015, the central governments of 40 countries, excluding China, were full or majority owners of nearly 2,500 SOEs collectively valued at $\$ 2.4$ trillion and employing over 9 million people. ${ }^{12}$ On its own, China's central government

${ }^{108}$ See, e.g., Andrei Shleifer \& Robert W. Vishny, Politicians and Firms, 109 Q. J. EcoN. 995 (1994).

${ }^{109}$ What Did Lava Jato, Brazil's Anti-Corruption Investigation, Achieve?, THE ECONOMist (Mar. 9, 2021), https://www.economist.com/the-economist-explains/2021/03/09/what-didlava-jato-brazils-anti-corruption-investigation-achieve.

${ }_{110}$ John B. Goodman \& Gary W. Loveman, Does Privatization Serve the Public Interest?, Harv. Bus. Rev., Nov.-Dec. 1991, at 26.

${ }^{111}$ Id.

112 Organisation ror Econ. Coop. \& Dev., The Size and Sectoral Distribution of StATE-OWNed ENTERPRISES 8 (2017), http://dx.doi.org/10.1787/9789264280663-en. 
portfolio of SOEs is vastly larger than that of the other 40 countries combined. ${ }^{113}$ SOEs are not only numerous; they are increasingly important actors in the global economy. Over the period from 2005 to 2014, the percentage of SOEs among the Fortune Global 500 increased from $9 \%$ to $23 \% .{ }^{114}$ In 2018, the number of Fortune Global 500 SOEs reached 107.115

The revival and transformation of SOEs were fueled in part by developments in the capital market. "Corporatization" of SOEs emerged as a favored alternative to complete privatization as a means of addressing their governance deficiencies and improving their performance. Corporatization refers to the process of transforming an SOE from a unit of government into a joint stock corporation with a board of directors and some percentage of the outstanding shares issued to the government, with the rest being sold to investors, in at least a surface attempt to separate the government's dual roles as investor and regulator. In stark contrast to the SOEs of prior eras, corporatization has permitted the shares of SOEs to be listed on stock exchanges, where some of the risk of the enterprise is transferred to public (non-state) investors and a measure of market discipline and transparency is provided by the capital market, without which private capital presumably would be unwilling to invest. Note that this constraint need not prevent the government from using the corporation as a policy-channeling tool, since the government's influence is not measured solely by the percentage of stock the government owns. ${ }^{116}$ As of 2015, listed SOEs ${ }^{17}$ accounted for $45 \%$ of all SOEs by value and $25 \%$ by employment. ${ }^{118}$ Unlisted majority-owned SOEs comprise just $29 \%$ of the total enterprise value of all SOEs. ${ }^{119}$ Thus, while these partially privatized corporations are still widely known as "SOEs," most of

${ }^{113}$ China's central government has a portfolio of 51,000 SOEs valued at $\$ 29$ trillion. Id.

${ }^{114}$ PwC, State-Owned Enterprises: Catalysts for Public Value Creation? (2015), https:// www.pwc.com/gx/en/psrc/publications/assets/pwc-state-owned-enterprise-psrc.pdf. Virtually all SOEs take the corporate form. $92 \%$ of the SOEs by value ( $84 \%$ by employment) are incorporated according to their country's general corporation law. Id. at 21 .

${ }^{115}$ Brandon Pizzola et. al., Insight: The Changing Headquarters Landscape for Fortune Global 500 Companies, BloOMBERG Dally TAx ReP. (Nov. 15, 2019), https://www.bna.com/ insight-changing-headquarters-n57982093842/. Much of the reemergence of the SOE is attributable to China's economic ascension over the past two decades. In an OECD study on seven non-member countries as of the end of 2015 , China accounted for over $75 \%$ of the 628 listed companies with majority or minority state shareholdings, and almost $85 \%$ of their combined market value of approximately $\$ 4$ trillion. As of the end of 2017 , over $30 \%$ of the companies listed on China's A Share market (60\% of market capitalization) trace their ultimate control to the central or local governments. Daniei. H. Rosen et al., Missing Link: Corporate GovERNANCE IN ChINA'S STATE SFCTOR, 12 (2018), https://asiasociety.org/sites/default/files/inlinefiles/ASNC_Rhodium_SOEReport_0.pdf.

${ }^{116}$ Curtis J. Milhaupt \& Wentong Zheng, Beyond Ownership: State Capitalism and the Chinese Firm, 103 GEO. L.J. 665 (2015) (arguing that equity ownership by the Chinese state is not a reliable measure of its ability to influence state-owned and privately-owned firms to carry out its policy goals).

${ }^{117}$ Defined as enterprises whose shares are traded on a stock exchange and in which the state holds at least $50 \%$ of equity or otherwise exercises an equivalent degree of control.

${ }^{118}$ PwC, supra note 114 , at 9 (citing the 2014 OECD report).

${ }^{119} \mathrm{Id}$. 
the large, globally active SOEs are more accurately thought of as mixed ownership enterprises in the sense that private investors have put up significant amounts of the corporation's capital. But, as noted, the percentage of private ownership is not a reliable measure of the state's ability to use the corporation as a policy-channeling tool. Consequently, the broad category of interest may more accurately be called the state-controlled or influenced enterprise ("SCIE").

As the most important contemporary illustration of the SOE/SCIE's comeback in the global economy, we turn now to China, where the corporate governance system in the reform era has exhibited its own pattern of oscillation, from an early use of the capital markets to support SOEs, to the emergence of private firms with superior financial performance and greater contributions to the economy, followed by an abrupt return to an SOE-centered governance system and increased political intervention to achieve the Party's policy objectives.

The creation of China's modern stock markets in 1990 was an important step in Deng Xiaoping's policy of economic opening and reform. The stock markets provided access to private capital as a means to fund SOE restructuring and facilitated a measure of external discipline on their managers. State-run businesses were hived off of government bureaus, cloaked in corporate form with the standard set of attributes provided by a newly adopted Corporate Law, and packaged for listing on the stock exchanges. ${ }^{120}$ The outcome of this process was a large number of publicly listed companies over which the party-state retained effective control or influence-a process of corporatization without privatization. ${ }^{121}$

For many years of China's economic rise, the capital market remained a tool for economic strategists in the Chinese government rather than the private sector. Quotas were maintained for IPOs, which were filled exclusively by SOEs undergoing restructuring. ${ }^{122}$ The structure of the SOE regime that emerged in the early 2000 s reveals its policy orientation. Despite the formal organizational transformation and public listing of the SOEs, control remained with the party-state, not principally as a result of its equity owner-

${ }^{120}$ For a critical account of this process, see CARL E. WALter \& Fraser J.T. HowiE, Red Capitalism: The Fragille Financial Foundations of China's Extraordinary Rise (rev. ed. 2012) ("Where did such Fortune Global 500 heavy hitters as Sinopec, PetroChina, China Mobile and Industrial and Commercial Bank of China come from? The answer is simple: American investment bankers created China Mobile out of a poorly managed assortment of provincial posts and telecom entities and sold the package to international fund managers as a national telecommunications giant.").

${ }^{121}$ Nicholas Howson, China's "Corporatization without Privatization" and the Late Nineteenth Century Roots of a Stubborn Path Dependency, 50 VAND. J. TRANSNAT'L L. 961 (2017). Milhaupt \& Zheng, supra note 116, make clear that the discontinuity between stock ownership and actual party-state influence creates a significant problem in applying western regulatory structures, which typically treat control and influence as being accurately measured by stock ownership, to Chinese mixed ownership companies.

${ }^{122}$ See Katharina Pistor \& Chenggang Xu, Governing Stock Markets in Transition Economies: Lessons from China, 7 AM. L. \& ECON. REv. 184 (2005). 
ship or through the functioning of corporate governance organs such as shareholders meetings and boards of directors, but through political mechanisms. ${ }^{123}$ Party committees were established within China's holding company for central SOEs (known as SASAC) ${ }^{124}$ and, pursuant to Chinese Company Law, within each SOE group member corporation. ${ }^{125} \mathrm{~A}$ dual corporate and party personnel system in SOEs ensures that senior SOE managers show fealty to the Party. Overlaps between the two systems are rather uniform, such that a corporate manager of a given rank typically holds a position of equivalent rank in the party system. The Party, working through SASAC and the company-level party committees, is able to influence boards of directors in the appointment, removal, remuneration, and supervision of senior managers and with respect to major business decisions. Institutionalized party penetration of the corporate form thus mirrors the Leninist practice of creating a parallel party governance structure vis-à-vis the organs of the state.

As is apparent from these regime design features, maximizing private investor value has never been the ultimate goal of this state system of corporate ownership. China's leaders view the SOE/SCIEs as a means of maximizing the state's utility in nonpecuniary as well as pecuniary ways, and at the country level, rather than at the firm level. From one perspective, the scale and results of this process are truly impressive. As of the end of 2017, SASAC was the sole shareholder of 97 parent holding companies of business groups containing 340 publicly listed subsidiaries, ${ }^{126}$ many of which are Fortune Global 500 companies. A single SOE business group under SASAC's control may have a labyrinthine network of over 100 subsidiaries, several of which may be linked through equity ownership to firms in other SOE business groups. ${ }^{127}$ The ownership structure of China's central SOEs might be loosely analogized to a single massive, diversified Korean chaebol business group where the party-state (acting through SASAC) plays the role of founder and controlling shareholder, with the greater capital market completeness reflected by formally mixed ownership serving to create business entities that also serve party-state purposes, limited at the margin by the need to support stock prices and future SOE financing.

Gradually, privately owned enterprises ("POEs") were permitted to access the capital markets, and POEs began to play an increasingly important

${ }^{123}$ For an extensive treatment of the subject, see Li-Wen Lin \& Curtis J. Milhaupt, We are the (National) Champions: Understanding the Mechanisms of State Capitalism in China, 65 Stan. L. Rev. 697 (2013).

${ }^{124}$ The State-Owned Assets Supervision and Administration Commission ("SASAC") is an agency formed under the State Council (cabinet) ostensibly acting as an investor on behalf of the Chinese people.

${ }^{125}$ The degree to which these committees are operational as opposed to symbolic varies among SOEs. The committees may at times perform supervisory and personnel functions, and may have overt political dimensions, such as building allegiance to party principles and disseminating campaigns announced by senior government leaders.

${ }^{126}$ Author calculations based on publicly available information.

${ }^{127}$ For a startling visual presentation of a single SOE business group under SASAC control, see Lin \& Milhaupt, supra note 123 , at 733 fig.5. 
role in the Chinese economy. The financial performance of private firms overtook that of SOEs, particularly after the state sector became burdened with debt resulting from the government's use of SOEs to stimulate the economy in the wake of the Global Financial Crisis. ${ }^{128}$ Today, the private sector leads the SOE sector in contributions to GDP (60\%), innovation (70\%), urban employment $(80 \%)$, new jobs $(90 \%)$, investment $(70 \%)$, and exports $(90 \%){ }^{129}$ Private firms such as Alibaba and Tencent have attained technological prowess and global brand recognition that eludes most of China's SOEs. By early in the second decade of the twenty-first century, economist Nicholas Lardy was able to assert that China's long economic reform process had reached the point where China was a "predominantly market economy in which private firms have become the major source" of growth and job creation. ${ }^{130} \mathrm{He}$ predicted that the $\mathrm{Xi}$ Jinping administration would deepen market-oriented reforms and roll back reliance on SOEs. China appeared to be on the cusp of an enduring shift in the relative weights of capital market completeness and policy channeling in its corporate governance system.

The shift proved ephemeral, however, as President Xi moved forcefully to return the corporate governance system's central objective to policy channeling by once again elevating the role of SOEs in the economy. ${ }^{131} \mathrm{Xi}$ declared that SOEs are "the basis for socialism with Chinese characteristics," serving as "supporting forces for the Party to govern and prop up the country." 132 In an October 2016 speech, Xi urged SOE managers "to bear in mind their number one role and responsibility is to work for the party." 133 Nonetheless, Xi recognized that doubling down on the SOE sector would require its improved financial performance, and SOE reform has been a centerpiece of the administration's agenda. A key aspect of the strategy is "mixed ownership" reform, namely, a plan to inject more private capital into publicly listed SOEs and to convert more SOEs to firms in which the

${ }^{128}$ Across a variety of measures, China's private sector significantly outperforms the state sector, and the performance gap is widening. For example, relative to the private sector, a higher percentage of state-sector firms have negative cash flows, while the state sector has lower returns on equity and lower cumulative earnings growth. Bradley Crom \& Matt Wagner, Evaluating Recent Fundamental Trends in Chinese Ex-State-Owned Enterprises, WISDOMTREE: (July 12, 2018), https://www.barrons.com/articles/sponsored/evaluating-recent-fundamentaltrends-in-chinese-ex-state-owned-enterprises-1531257141?tesla $=$ Y. Return on equity of listed SOEs declined by half from 2007-2017. Yusho Cho \& Kenji Kawase, How China's StateBacked Companies Fell Behind, Niknfi Asınn Rev. (May 23, 2018), https://asia.nikkei.com/ Spotlight/Cover-Story/How-China-s-state-backed-companies-fell-behind.

${ }^{129}$ World Econ. F., The Role of China's State-Owned Companies Explained (2019), https://www.weforum.org/agenda/2019/05/why-chinas-state-owned-companies-still-have-akey-role-to-play/. (2014).

${ }^{130}$ Nicholas R. Lardy, Markets Over Mao: The Rise of Private Business in China

${ }^{131}$ The title of Lardy's next book illustrates the volte-face: Nicholas R. LARdy, ThE

State Strikes Back: The End of Economic Reform in China? (2019).

${ }^{132}$ Cho \& Kawase, supra note 128.

133 ld. 
state and private shareholders hold joint equity stakes. ${ }^{134}$ The objective is to increase capital market discipline on SOEs to improve their financial performance without relinquishing state control. In effect, the latest turn in the Chinese governance cycle displays the ambition to harness a complementary operation of capital market completeness and policy channeling.

But what happens to policy channeling when state ownership is diluted with larger doses of private investment, and when the leaders of very large private firms such as Alibaba and its fintech offshoot Ant Group criticize the regulatory systems in which they operate? This question is of obvious concern to China's leaders, and interestingly harkens back to Berle and Means' unease over the separation of ownership and control, although for very different reasons. In recent years, high-level government and party organs have issued policies seeking to reinforce the Party's leadership in SOEs, and the principle of party leadership in SOEs has recently been enshrined in the Constitution of the Chinese Communist Party. ${ }^{135}$ Guidelines issued by SASAC and the Ministry of Finance provide a template for SOEs to amend their Articles of Association so as to weave the principle of party leadership into their constitutive documents. About 90 percent of publicly listed SOEs have adopted some form of these amendments, ${ }^{136}$ the most substantive of which make the firm's internal Communist Party committee superior to the board of directors and corporate managers with respect to major decisions and senior management appointments. ${ }^{137}$ The need to deal with the separation of management and control that motivated Berle's belief that the government needed to act as a counterweight to management plays out differently in China: the party-state acts as a counterweight to private investors to secure the corporation's role as a vehicle for policy channeling.

Party influence over large private firms is also increasing in various ways, including via party involvement in corporate governance and equity investment by the state. ${ }^{138}$ The most dramatic evidence of the Party's concern

${ }^{134}$ In September of 2015, the State Council adopted detailed guidelines on the implementation of these mixed ownership reforms.

135 See, e.g., Guming Opinions of the Cenntral Committee of the Communist Party of China and the State Councli, on Deepening State-Owned Enterprise Reform, item I.2. ("Insist on the leadership of the State-owned enterprises by the party"); Constriution of this Communist Party of Chins of Oct. 24, 2017, art. 33 (2017). ("The leading. . Party committees of state-owned enterprises shall play a leadership role, set the right direction. . . and discuss and decide on major issues of their enterprise in accordance with regulations.") (emphasis added).

${ }_{136}$ Yu-Hsin Lin \& Curtis J. Milhaupt, Party Building or Noisy Signaling? The Contours of Political Conformity in Chinese Corporate Governance, 50 J. LeGAl. STud. 187 (2021).

${ }^{137}$ Id.; see also Houze Song, State-Owned Enterprise Reforms: Untangling Ownership, Control, and Corporate Governance, MACro PoLo (Dec. 4, 2017), https://macropolo.org/ anaysis/state-owned-enterprise-reforms-untangling-ownership-control-corporate-governance/ ("decision-makers now favor putting the Party committee atop the board as the ultimate authority in an SOE").

${ }^{138}$ The controversy over telecom equipment maker Huawei's potential threat to national security in Western democracies is a prime illustration of how the fusion of Chinese Communist Party/government influence and corporate power has created globally important Chinese 
for loss of policy control at the hands of the private sector is the last-minute cancellation of fintech giant Ant Group's planned IPO (which would have been the world's largest) at the behest of Xi Jinping himself, following public criticism of China's regulatory approach to the fintech industry by Ant's founder, Jack Ma. ${ }^{139}$ The episode sends an unmistakable signal to the private sector that the capital market can be closed to firms that threaten the Party's carefully orchestrated socialist market economy system. ${ }^{140}$

Chinese policymakers thus seek to strengthen policy channeling by means of capital market completeness, facilitated through Chinese Communist Party infiltration of the corporate governance processes of publicly listed SOEs, and by increasing Party influence over large private firms. Since the Party is the ultimate authority of how different stakeholders are treated, China today may constitute the world's most extreme form of stakeholder-oriented corporate governance.

\section{Conclusion}

We have attempted, in these brief sketches of Japan and China, to highlight the universality of the binary forces at work in corporate governance wherever the corporation is the central actor in the economy. Equally importantly, we have also sought to highlight the importance of context in understanding where a particular country's corporate governance is located on the capital market completeness-policy channeling continuum and the direction in which it is shifting at a given moment in time. Japanese government policy is embracing capital market (shareholder) oriented corporate governance - with considerable hesitation and some pushback from the private sector-at the very time the U.S. and the U.K. are shifting in the direction

firms with features and externalities unlike those of firms found in any other country. Some of the party infiltration into private firm governance is happening at the behest of the private sector itself. See Lin \& Milhaupt, supra note 136 (finding that six percent of private Chinese listed companies voluntarily adopted "party building" amendments to their corporate charters, notwithstanding the fact that the policy was not required for the private sector). Recently, the Chinese government has begun acquiring equity stakes in private firms. See, e.g., Li Yuan, Private Business Built Modern China. Now the Government is Pushing Back, N.Y. Trmes, (Oct. 3, 2018), https://www.nytimes.com/2018/10/03/business/china-economy-private-enterprise.html (reporting growing government interest in taking stakes in private firms, in part to pay for social programs and deal with externalities such as pollution).

${ }^{139}$ See, e.g., Lingling Wei, Jack Ma Makes Ant Offer to Placate Chinese Regulators, WAL.L S. Г. J. (Dec. 20, 2020), https://www.wsj.com/articles/jack-ma-makes-ant-offer-to-placate-chinese-regulators-11608479629 (quoting Ma as offering regulators "any of the platforms Ant has, as long as the country needs it" to make amends for the speech which precipitated cancellation of Ant's IPO); Xie Yu, China Tells Ant Group to Refocus on Its Payments Business, Wal. ST. J., Dec. 27, 2020 (reporting on the Chinese central bank's harsh rebuke of Ant's corporate governance and approach to regulatory compliance).

${ }^{140}$ See Rupert Neate, China Orders Alibaba founder Jack Ma to Pare Down Fintech Empire, The Guardian (Dec. 28, 2020), https://www.theguardian.com/business/2020/dec/28/ china-orders-alibaba-founder-jack-ma-break-up-fintech-ant (quoting an observer as remarking, "The Party has once again reminded all private entrepreneurs that no matter how rich and successful you are it can pull the rug out from under your feet at any time."). 
from which Japan is departing. Meanwhile, after suffering a near-death experience with the collapse of the Soviet Union and Eastern Europe, state ownership has staged a remarkable comeback in the first two decades of the twenty-first century, as governments rediscovered the utility of the corporation as a means of carrying out policy and as China powerfully emerged under an interventionist party-state making heavy use of the SOE/SCIE as an engine of development and soft power. Today, despite the emergence of a dynamic private sector and predictions of a thorough rollback of the state, the Chinese government appears intent not only on reinvigorating the policy channeling role of the SOE/SCIE in the economy but extending it to private corporations as well.

\section{Where in the Governance Cycle are We Now?}

So where is corporate governance in the Hirschman cycle circa the third decade of the 21 st century? As our essay suggests, there can be no single answer to this question-different countries are at different points in the cycle, which in turn reflects the familiar point that every country's governance system is constructed out of the bricolage of its particular history. We focus here on the United States, offering shorter reflections on Japan and China.

By this point in our essay, readers will have anticipated the answer for the United States: a more complete capital market has reduced management's discretion and generated an increased focus on shareholder value, leading to a rebound in the direction of policy channeling and a corresponding focus on stakeholders. In this concluding section, we provide a short overview of two related channels through which this rebound is occurring: the emergence of the notion that institutional investors should serve as "stewards" in the governance of the public corporations in their portfolios; and the associated concept that a public corporation should have a stated "purpose" beyond the generation of shareholder profits.

As we will see, both channels can be understood as a direct response to increased capital market completeness reflected by the reconcentration of equity in the hands of large institutional investors that we outlined in Part II; $;{ }^{141}$ each seeks to harness those concentrated voting rights to the end of a more extensive stakeholder orientation rather than a vehicle that reduces management's protection from capital market discipline. With respect to stewardship, it is rather ironic that commentators sympathetic to increased policy channeling and more stakeholder-focused governance are now relying on the very same institutional investors that voted for activists in proxy con-

${ }^{141}$ This concentration is most pronounced in the U.S., U.K., and Canada, but it is not limited to those markets. Worldwide, institutional investors own $41 \%$ of the equity of publicly listed companies (by market capitalization). A. De La Cruz et al., Organisation for Econ. Coop. \& Dev., Owners of the World's Listed Companies, 11 (2019), https://www.oecd.org/ corporate/ca/Owners-of-the-Worlds-Listed-Companies.pdf. 
tests to support a shift away from market completeness. It was the reconcentration of equity in institutional investors that, through activists, gave rise to a shift toward capital market completeness, and so to even more attention to shareholder value maximization in the first place. Because the increased ownership by institutional investors animates the greater constraints on management resulting from the new role of activist investors, a Hirschman-like rebound toward stakeholderism necessarily requires turning large institutional shareholders away from shareholder value maximization and constrained managerial discretion because these are suddenly viewed by the Business Roundtable as the dark side of capital market forces. ${ }^{142}$

These related channels-stewardship and corporate purpose-have generated a large literature that is beyond our ambition to survey here. ${ }^{143} \mathrm{We}$ want simply to peg the current location of our binary corporate governance system and to underscore reasons why, given its cyclical character, the current phase is likely to be as transient as those that came before it.

\section{A. The First Channel: Stewardship}

The first channel through which disappointment with increased capital market discipline was funneled was the emergence of the stewardship concept. This is the notion that large institutional investors, especially the very large index funds, should be "stewards" of their portfolio companies-active performance and governance monitors, and proactively engaged with management to address problems with either. Institutional investors are said to be long-term shareholders sensitive to claims that activists are too focused on the short-run. ${ }^{144}$ This is tautologically true of index funds, whose portfolio holdings are constant except as a result of changes in the index or rebalancing. ${ }^{145}$

Our goal here is only to highlight the difficulties institutional investors face in acting as effective stewards. ${ }^{146}$ Their ineffectiveness can be expected to shorten the time until the next Hirschman-esque rebound. The potential

${ }^{142}$ See The Bus. Roundtable, supra note 13.

${ }^{143}$ On stewardship, see, e.g., Jennifer Hill, Good Activist/Bad Activist, The Rise of International Stewardship Codes, 14 SEATTI.E U. L. REv. 497 (2018); on corporate purpose, see, e.g., Edward B. Rock, For Whom is the Corporation Managed in 2020? The Debate Over Corporate Purpose (Working Paper 2020), https://papers.ssrn.com/sol3/papers.cfm?abstract_id= 3589951; MAYER, supra note 4; BRIT. ACAD., supra note 5.

${ }_{144}$ See, e.g., Robert C. Pozen, The Role of Institutional Investors In Curbing Corporate Short-termism (2015), https://www.brookings.edu/articles/the-role-of-institutional-investorsin-curbing-corporate-short-termism/; Larry Fink, Letter to Chief Executives Bı.ACKROCK (2016), https://www.blackrock.com/corporate/investor-relations/2016-larry-fink-ceo-letter, ("Today's culture of quarterly earnings hysteria is totally contrary to the long-term approach we need.").

${ }_{145}$ See, e.g., Adriana Robertson, The (Mis)Uses of the $S \& P$ 500, (Working Paper 2018), https://papers.ssrn.com/sol3/papers.cfm?abstract_id $=3205235$.

${ }_{146}$ An earlier effort to draft institutional investors as what now would be called "stewards" dates back to the early 1990s and had as its goal an increase in shareholder value maximization rather than policy channeling and more attention to stakeholders. See, e.g., Ronald J. 
for large institutional investors to make a significant contribution as stewards is in the first instance a function of the size and concentration of their holdings, both of which serve to assure that the intended objects of stewardship are inclined to listen.

Institutional investors now easily meet both the size and concentration criteria. In 2020, institutions owned some $70 \%$ of the outstanding stock of U.S. publicly traded corporations. ${ }^{147}$ These large holdings are also highly concentrated, dramatically reducing the frictions associated with cooperation: as of May 2020, the largest $1 \%$ of investment company groups managed $61 \%$ of total industry assets, some 243 times the aggregate holdings of the bottom 50\%. As well, the concentration is growing: the difference in the 2020 holdings of the largest $1 \%$ of fund families compared to the bottom $50 \%$ is 2.3 times larger than the difference just 10 years earlier. ${ }^{148}$ Finally, the composition of funds is moving dramatically toward index funds and so to asset managers with sufficient assets under management to capture the economies of scale associated with passively managed index funds. The increased concentration of index fund managers is even more skewed toward the three largest index operators: Blackrock, Vanguard, and State Street Global Advisors. From 2010 through 2019, indexed equity funds and ETFs (exchange traded funds) had net positive cash flows of $\$ 1.8$ trillion, $\$ 1.7$ trillion of which roughly matched the net negative cash flows from actively managed funds-a massive shift from active to passive portfolio management. ${ }^{149}$ From 2009 through 2019, Blackrock, Vanguard, and State Street Global Advisors garnered $82.4 \%$ of all asset inflows into equity mutual funds and ETFs. ${ }^{150}$

The stewardship concept took on a high profile with the adoption by the U.K. Financial Reporting Council's 2010 Stewardship Code ${ }^{\mid 51}$ in response to the Great Recession triggered by the 2008 collapse of Bear Stearns and Lehman Brothers and the need for an overnight (more precisely, over the week-

Gilson \& Reinier Kraakman, Reinventing the Outside Director: An Agenda for Institutional Investors, 43 STAN. L. REv. 863 (1991).

${ }^{147}$ Posner et al., supra note 72.

${ }^{148}$ Siobhan Riding, Trillion-dollar Club Tightens Grip on Fund Market During Crisis, Fin. Timrs (May 9, 2020), https://www.ft.com/content/a6aa1010-3dff-4521-af52fbadb496c89d.

${ }^{149}$ Investment Company Instrtute, Investment Company 2020 Fact Book, fig. 3.4 (2020). For additional information concerning the growing concentration of equity mutual funds and the shift from passive to active management, see, e.g., Coates, supra note 74; Lucian A. Bebchuk \& Scott Hirst, Index Funds and the Future of Corporate Governance: Theory, Evidence and Policy, 119 Col. L. Rev. 2029 (2019); Edward Rock \& Marcel Kahan, Index Funds and Corporate Governance: Let Shareholders be Shareholders (Eur. Corp. Governance Inst., Law Working Paper No. 467/2019), https://ssrn.com/abstract=3295098; Gilson \& Gordon, supra note 69.

${ }^{150}$ Lucian A. Bebchuk \& Scott Hirst, The Specter of the Giant Three, 99 Boston U. L. REV. 721, 732 (2019).

${ }^{151}$ Fin. RePORTing COUNCIL, UK Stewardship Code, (2010), https://www.frc.org.uk/getattachment/e223e152-5515-4cdc-a951-da33e093eb28/UK-Stewardship-Code-July-2010.pdf. 
end) bail out of AIG. ${ }^{152}$ The 2010 U.K. Code was then revised in 2012 and $2020^{153}$ and matched by the adoption of somewhat similar codes in many other countries. ${ }^{154}$

From the outset, however, even this brief account of the stewardship movement's origins presents a puzzle that gives rise to skepticism concerning the overall enterprise. Institutional investors held sufficient shares going into the Financial Crisis to influence the outcome of most activist proxy fights and to command the attention of portfolio company management should the institutions have determined to engage. Thus, institutions had the power to act as stewards and were sufficiently concentrated that coordination costs would not have been a barrier. But if the biggest financial crisis since the Great Depression was the result of commercial and investment banks engaging in excessive risk-taking, where were the powerful institutional shareholders whose capacity for stewardship should have provided the skills to see the disaster coming and the power through their equity holdings to prevent it? ? $^{155}$

The current stewardship concept thus represents a (largely) non-regulatory response to this non-rhetorical question. ${ }^{156}$ It is a Hirschman-like reaction to disappointment with the results of increased focus on shareholder

${ }^{152}$ See, e.g., Brian R. Cheffins, The Stewardship Code's Achilles' Heel, 73 MoD. L. REv. 1004 (2010) (surveying background on adoption of UK Stewardship Code). On the financial crisis, see, e.g., Ben Bernanke, The Courage to Act: A Memoir of a Crisis and its Aftermath (2015); on the AIG crisis and rescue, see, e.g., Timothy Geithner, Stress Test: Reflections on Financial Crises (2015).

${ }^{153}$ Fin. Reporting Council, UK Stewardship Code (2012), https://www.frc.org.uk/investors/uk-stewardship-code/2012-uk-stewardship-code-(1); Fin. REPoRTING CouncIL, UK Stewardship Code (2020) frc.org.uk/getattachment/5aae591d-d9d3-4cf4-814a-d14e156a1d87/ Stewardship-Code_Dec-19-Final-Corrected.pdf.

${ }^{154}$ See Hill, supra note 143, at 497, which nicely tracks the spread of stewardship codes internationally and the different approaches taken by different countries. Although the language of the codes is similar, the purposes to which these codes have been put varies significantly across countries. See Dan W. Puchniak \& Earnest Lim, The False Hope of Stewardship in the Context of Controlling Shareholders: Making Sense Out of the Global Transplant of a Legal Misfit, (Eur. Corp. Governance Inst., Law Working Paper No. 589/2021, 2021). The European Corporate Governance Institute website provides access to copies of countries' stewardship codes. See Codes, Eur. Corp. Governance INST,, https://ecgi.global/content/codesstewardship?field_categories_tid=stewardship (last visited Feb. 9, 2022).

${ }^{155} \mathrm{~A}$ familiar reference to Citicorp makes the point. When its CEO, Charles Prince, was asked in 2007 why he did not cause the bank to withdraw from the riskiest part of the leveraged buyout market, he is said to have replied that "as long as the music is playing, you've got to get up and dance." Michiyo Nakamoto \& David Wighton, Citicorp Chief Stays Bullish on Buyouts, Fin. Times (July 9, 2007), https:/www.ft.com/content/80e2987a-2e50-11dc-821c$0000779 \mathrm{fd} 2 \mathrm{ac}$. In this regard, note that Citicorp had a very large, friendly investor who had the power to make the imposition of capital market discipline difficult; it was not clear of whom Prince was afraid.

${ }^{156}$ Dodd-Frank Wall Street Reform and Consumer Protection Act, Pub. 111-203, 124 Stat. 1376 (2010). Most stewardship and corporate governance codes are not mandatory. In contrast, the U.S. response took the form of massive new regulation with hundreds of provisions sprawling over more than 2000 pages of text. The statute anticipated the mandatory issuance of thousands more pages of regulations, which created new financial regulatory agencies and addressed everything from the quality of credit ratings to hedge fund registration, and from derivatives trading to the Federal Reserve's emergency loan power. 
value maximization - a response that relies upon the very intermediation that greatly enhanced this focus as a tool to dilute it.

As we saw in Part II, equity intermediation created a shareholder distribution in which large institutional owners came to collectively control more than $70 \%$ of the outstanding shares of publicly traded corporations. The business model of, for example, advisors to large actively managed mutual funds, is to increase the value of the assets under the fund's management (AUM). Because the mutual fund advisor's compensation is typically set as a percentage of AUM, decisions that increase the value of the shares in a fund's portfolio also increase the advisor's compensation. If stewardship is going to be successful, active portfolio managers are going to be crucial; it is these alpha-secking professionals who have the skills to evaluate the performance and strategy of portfolio companies, which seems intuitively the core of a steward's responsibility.

The incentive to manage a fund to increase AUM, and hence the advisor's (and portfolio manager's) compensation, is powerfully reinforced by a collateral effect of an active fund advisor's success in increasing the value of the fund's assets. AUM rises with increases in the value of the existing portfolio; but it also rises as a result of asset inflows from new purchases of the fund's shares, presumably as a result of the fund's positive relative performance. Better performance of a fund's shares thus results in two different sources of rising AUM.

Translated into governance terms, the result of AUM-based advisor compensation is to make funds likely to accept a hostile bid at a premium; if the advisor accepts the premium bid on behalf of fund shareholders by tendering the fund's target shares, the value of fund shares increases to the extent of the premium, benefitting both fund shareholders and, because investors shift their investments to funds whose assets grow the most, giving the fund advisor an incentive to increase its AUM by accepting a premium bid. The bid's premium over market increases the beneficiaries' absolute return and, to the extent that other funds do not either own the target's shares or tender into a successful offer, increases the fund's relative performance as well: the better performing funds draw assets away from less well performing funds.

This incentive led fund advisors to oppose barriers to a portfolio company's exposure to the capital market and made them receptive to hostile bidders offering a premium for their shares. Thus, it became commonplace for mutual funds to announce on their websites that they would vote against defensive tactics that allow portfolio company management to block a hostile premium bid, for example, through the adoption of a poison pill or a staggered board. ${ }^{157}$

${ }^{157}$ See, e.g., BLACKRock, Corporate Governance and Proxy Voting Guidelines for U.S. Securities (2021), at 5, 7, 9, https://www.blackrock.com/corporate/literature/fact-sheet/blk-responsible-investment-guidelines-us.pdf (opposing staggered boards and "most" poison pills). 
This package of institutions' incentives then led, at least on company management's part, to a Hirschman-like reaction away from market completion and toward policy channeling: from shareholder value maximization toward a stakeholder orientation and more protection for management from capital market discipline. For this to work, however, it was necessary, somehow, to encourage large fund advisors to resist premium hostile bids if it in good faith thought the target's long-term value exceeded the premium offered, to vote against an activist's complementary strategic proposal if a proxy fight resulted and, more generally, to be more patient than the institutions' voting policies and market conditions currently contemplate. As the issue came to be framed, institutional investors had to be persuaded to favor long-term investment over short-term profits (putting aside the question of whether it is plausible that advisors can assess the proper discount rate) and to feel good about it.

And so arose the concept that institutional investors should be stewards with respect to their portfolio companies. As set out in the 2019 U.K. Revised Stewardship Code, "[s]tewardship is the responsible allocation and management of capital across the institutional investment community to create sustainable value for beneficiaries, the economy and society....This definition identifies the primary purpose of stewardship as looking after the assets of beneficiaries that have been entrusted to the care of others." 158 In this sense, the stewardship concept is the Hirschman-esque corollary of the reconcentration of equity: rather than focusing only on the fund advisor's profits and thus the performance of their beneficiaries' investment, the policy requires a broader integration of the interests of "the economy and society." The push is for capital market completeness to give way to policy channeling.

But that framing of stewardship then poses a straightforward question: will it succeed? Is the stewardship role consistent with the steward's business model ? $^{159}$ Will we see stewards who get their hands dirty by working the fields or, instead, English landed gentry who like the mantle but have little real interest in the effort?

The answer will be shaped by the economics of asset management, and the outcome powerfully influenced by two developments in that business that took place roughly contemporaneously with the reconcentration of eq-

${ }^{158}$ Fin. Reporting Counci,, Proposed Revision to the UK Stewardship Code, at Annex A - Revised UK Stewardship Code 1 (2019).

${ }^{159}$ We note here that the discussion in the text assumes that the institutional investor is a profit-making enterprise whose ability to attract funds depends on its performance. In other words, a potential investor in a would-be stewardship-oriented fund has choices as to with whom it will invest and so the fund faces market pressure toward shareholder value maximization. In contrast, institutional investors who have locked-in investors-a flow of funds that can only be invested in the stewardship-oriented fund-are sheltered from the incentive effect of absolute and relative performance. Such locked-in investor funds would include, for example, U.S. state-level public employee pension funds like the California Public Employee Retirement System, and sovereign wealth funds like those of Singapore and Norway. 
uity through intermediation. These were first the massive shift of AUM from actively managed funds seeking alpha-returns that exceed the risk-adjusted market return-to index funds that seek only to mechanically deliver the same returns as the particular index that it tracks; and second, the resulting sharp decline in management fees for both index and actively managed funds. ${ }^{160}$

To this point we've seen that intermediary institutional investors have sufficient ownership to be able to influence, but not necessarily dictate to, portfolio company management and that the investment management market is sufficiently concentrated that parallelism can support cooperation. The last question is whether they have the resources to effectively discharge a stewardship role. Answering this question requires a greater focus on what stewards actually do.

The arrows in the stewardship quiver can be roughly categorized as monitoring, voting, and engagement. Although both monitoring and engagement may be preconditions to a steward discharging its voting role, it is useful to be more precise about the scale of voting involved and the type of issues presented to the shareholders. An S\&P 500 index fund, for example, will cast thousands of votes a season, covering the issues presented to shareholders by the fund's 500 portfolio companies, a number that would seem overwhelming absent recognition that the great percentage of votes are routine, for example, approving a company's outside auditor, that involve little expense in determining how to vote. To be sure, the costs of actually voting, as opposed to deciding how to vote, would still be significant were the fund to have to maintain the administrative apparatus necessary to mechanically cast this number of votes, but the leading proxy advisors like ISS and Glass Lewis mitigate this problem by providing a service that undertakes the mechanical casting of a fund's votes pursuant to the directions given by the fund. ${ }^{161}$

160 The scale-driven decline in management fees for index funds, together with the fact that index funds have outperformed actively managed funds on a net basis for a significant period of time, has caused the management fees for the largest index funds to range from zero to $0.3 \%$. How can institutional investors make money without charging for the service provided? As we will discuss in notes 163-166 infra, index fund managers share in the fees made from lending securities to investors who wish to short a stock. Using securities lending as a source of revenue, however, can create conflicts with respect to discharging one of a steward's central roles: voting the portfolio's shares. We address this conflict in note 163 infra. A second qualification relates to an index manager's fees for expenses other than portfolio management. In almost all cases, the management fee covers only the amount paid to the fund advisor for investment advice. A separate fee is charged that covers all other expenses of the fund except for distribution of fund shares, which cannot be charged to investors under the Investment Company Act of 1940. On September 29, 2021, the SEC proposed Exchange Act Rule 10c-1, which would substantially increase disclosure of material information concerning securities lending. See Reporting of Securities Loans, 86 Fed. Reg. 69,802 (Dec. 8, 2021).

${ }_{161}$ The ISS website describes the firm's capacity to manage the mechanics of voting institutional investors' shares in the large number of portfolio company elections. See INST. S'Holdoer Srizvs., Proxy Voting Services, https://www.issgovernance.com/solutions/proxy-voting-services/ (last visited Feb. 9, 2022). 
The cost necessary to determine how to vote also can be overstated. Consider votes on portfolio company corporate governance structures such as poison pills, staggered boards, separate CEO and Board chair positions, and the like. These issues, which are hardly new, have already been addressed generally by large mutual funds, and their positions appear on their websites. To be sure, issues on which a general policy exists-say opposition to poison pills-may require investment of more resources when the vote is associated with what we will call a value or transactional vote: one that directly affects a portfolio company's stock price. For example, a company may want to adopt a short-term poison pill in connection with a particular hostile takeover or proxy fight rather than a standard 10-year pill; there is some evidence that anticipatory adoption can affect stock price even though the company's board can adopt a pill virtually overnight without a shareholder vote if it waits until a challenge to management appears. ${ }^{162}$ In that circumstance, a fund could be asked to approve a pill whose terms are tailored to the particular circumstance, such as a pill crafted to protect the tax status of a real estate investment trust or to protect against the forfeiture of net operating loss carryovers as a result of changes in ownership. Nonetheless, these are well-understood issues and do not require deep analysis.

A final concern about a steward's voting is driven by the compression of investment company margins resulting from the decline in fees for all categories of funds. Funds can earn revenues not only from management fees, but also from fees earned by lending their portfolio shares to those who wish to short the issuer's shares. While these fees are often shared between the advisor and the funds, share lending can create a conflict with the steward's voting obligations. If the fund's shares are on loan on the record date for a vote, the steward cannot vote them. This is particularly important in connection with a contested vote, when the fees for borrowing shares may be the highest. ${ }^{163}$

A recent extreme example illustrates the potential problem. In June 2020, GameStop Corp. faced a nasty proxy contest against two activist investors. The three largest shareholders held in the aggregate approximately $40 \%$ of the outstanding shares based on first quarter reports. At the time of the vote, however, their holdings were estimated to have been reduced to $5 \%$ of the votes. The drop was reported to have been the result of BlackRock, Vanguard, and Fidelity loaning out their shares and not recalling them (which would have resulted in the loss of loan fees) before the record date. ${ }^{164}$

${ }^{162}$ See Emiliano Catan, The Insignificance of Clear Day Poison Pills, 48 J. LEG. Stud. 1 (2019); Merritt B. Fox et al., The Core Corporate Governance Puzzle: Contextualizing the Link to Performance, 99 B. U. L. Rev. 1995 (2019) (addressing the circumstances when the adoption of a clear day poison pill may have a signaling effect).

${ }^{163}$ Joshua Mitts, Passive Exit (Colum. L. \& Econ. Working Paper, Paper No. 638, 2020), https://papers.ssrn.com/sol3/papers.cfm?abstract_id=3716249.

${ }_{164}$ Dawn Lim, Investing Giants Ceded Full Vote Power, WALI. ST. J., June 11, 2020, at B1, B10. 
The activists won the proxy fight. In this case, new borrowers of GameStop shares were said to have paid $80 \%$ to $190 \%$ of the value of the shares on an annualized basis. ${ }^{165}$ SEC guidance published in 2019 stated that funds could trade off its voting obligation against loan fees so long as they balanced their conflicting obligations to their client. ${ }^{166}$

That brings us to the core of the stewardship role: monitoring and engagement. The issues and the analysis are straightforward. As to the issues, the fund should function as an alternative to activist investors by assessing the performance of its portfolio companies and, when it believes it can provide guidance, engage directly with a company's management to influence company policies and strategy. ${ }^{167}$ As to the analysis, the fund has to determine how many portfolio companies must be monitored; the aspects of a firm's management and strategy that should be addressed; and the cost of monitoring and engagement. Lucian Bebchuk and Scott Hirst provide a detailed assessment of the number of portfolio companies a large fund family would need to monitor, the number of firms that would require direct engagement, and the costs of doing each. ${ }^{168}$ They conclude that the current stewardship practices of large fund families do not make a dent in what real stewardship would require.

The difficulty with the current stewardship effort, however, is not how much the funds do, but that they do the wrong things. ${ }^{169}$ From the perspective of the Hirschman cycle, the current move toward stewardship is a mirage; it does not effectively facilitate policy channeling and so is likely to

${ }^{165}$ Dawn Lim, How Investing Giants Gave Away Voting Power Ahead of Proxy Fight, MARKETSCREENER.COM (Jun. 10, 2020), https://www.marketscreener.com/quote/stock/ GAMESTOP-CORP-12790/news/How-Investing-Giants-Gave-Away-Voting-Power-Ahead-ofa-Shareholder-Fight-30751433/.

${ }^{166}$ Commission Guidance Regarding Proxy Voting Responsibilities of Investment Advisers, 84 Fed. Reg. 47,420 (Sep. 10, 2019). The SEC did not address how this balance would be undertaken. Commissioner Jackson issued a separate statement raising the concern that the incentive to vote would be reduced by security lending. Robert A. Jackson, Statement on Proxy-Advisor Guidance, Sec. \& Exсн. Comm'N (Aug. 21, 2019), https://www.sec.gov/news/ public-statement/statement-jackson-082119. Recent empirical evidence shows a marked increase by index funds in lending shares subject to a proxy fight rather than voting them. Hu et al., The Index Fund Dilemma: An Empirical Study of the Lending-Voting Tradeoff (Colum. L. \& Econ. Working Paper, Paper No. 647, 2020), https://ssm.com/abstract $=367531$.

${ }^{167}$ Note that the institutional investor playing this role substitutes for the complementarity of activist investors and institutional investors stressed by Gilson and Gordon, supra note 69, at 897. The expanded stewardship role shifts the activists' role to the institutional investor. For some of the stewardship advocates, this is precisely the point of the exercise. See Symposium, Session I: Corporate Purpose and Governance, 31 J. APPLIED CORP. Fin. 10, 23 (2019) ("Unless we can get the major investment institutions to buy into supporting purpose and culture, we will not solve the problem.").

${ }^{168}$ Lucian A. Bebchuk \& Scott Hirst, Index Funds and the Future of Corporate Governance: Theory, Evidence, and Policy, 119 Colum. L. Rev. 2029, 2076-80 (2019); see Jill E. Fisch, The Uncertain Stewardship Potential of Index Funds, in Global. Stewardship: ComPlexities, Challenges and Possibilties (manuscript at 101) (Dan Puchniak and Dionysia Katelouzou, eds., forthcoming), https://ssrn.com/abstracts $=3525355$.

${ }^{169}$ See Bebchuk \& Hirst, supra note 168, at 2095. 
give rise to a disappointment-driven responsive shift. To see this, consider what the large U.S. fund families actually do.

Voting, monitoring and engagement, as the funds describe their stewardship efforts, are all at least one step removed from actually improving the only thing both stockholders and stakeholders care about: the portfolio firm's actual performance, however defined. In this respect, we push a little further than Bebchuk and Hirst's careful demonstration that large funds do not engage in just those activities that actually would hold out the promise of better performance: they do not invest in identifying the problems that hinder the portfolio company's performance and formulate responses. ${ }^{170}$ And this is apparent from the employees the firms hire to run their stewardship program. Most surely, they are not the equivalent of active portfolio managers. Bebchuk and Hirst estimate an annual per employee cost of some $\$ 300,000$ for stewardship employees. In contrast, a serious active portfolio manager will be paid in the seven figures. The mismatch between stewardship employee skills and the task of engaging with a portfolio company over its strategy and performance is observable. Over the last 10 years, BlackRock substantially increased the number of employees in the stewardship group. ${ }^{171}$ In 2017, the company stated that it was reducing the number of active fundamental portfolio managers by some 10 percent. ${ }^{172}$ Employee costs were saved because more highly skilled employees were replaced by less skilled employees with a corresponding cost reduction and limit in the stewardship conception, in fact if not in rhetoric. ${ }^{173}$

Similarly striking is what large fund families do not do. Most importantly, they do not engage with portfolio companies over the identity of a company's directors, a matter of significance if the institutional steward is directly concerned with the portfolio company's performance and is expected to substitute for activist investors. Some 30 years ago Gilson and Kraakman designed a means for funds to influence director selection without seeking to influence control. ${ }^{174}$ To be sure, the fact that the Gilson and Kraakman structure has never been adopted may simply mean that it was poorly designed. But the fact that large fund groups still do not engage directly with poorly performing portfolio companies about the identity of the

$170 \mathrm{Id}$.

${ }^{171}$ Dawn Lim, BlackRock Power Broker Barbara Novick Is Stepping Down, WALL ST. J. (Feb 26, 2020), https://www.wsj.com/articles/blackrock-power-broker-barbara-novick-is-step ping-down-11582718402 $\bmod =$ searchresults\&page $=1 \&$ pos $=8$.

${ }^{172}$ Sabrina Willmer, BlackRock Cuts Dozens of Jobs and Fees in Stock-Picking Unit, BloOMBERG News (March 28, 2017), https:/www.bloomberg.com/news/articles/2017-03-28/ blackrock-said-to-cut-jobs-fees-in-revamp-of-active-equity-unit.

${ }^{173}$ Blackrock recently announced that it was increasing its total workforce by some 1800 new employees, representing $10 \%$ of total employees. The new hires were described as in "junior roles." Blackrock to Hire Up to 1800 Staffers, IGNites.COM, Jan. 18, 2022, https:// www.ignites.com/c/3464644/443833/blackrock_hire_staffers?referrer_module=emailMost Popular

${ }^{174}$ Gilson \& Kraakman, supra note 146. 
board reflects a severely crimped view of what effective stewardship would entail.

Whether or not our skepticism of stewardship in the U.K./U.S. conception turns out to be well placed, the situation in the other countries we surveyed in this essay could hardly be more different in their approach to this channel of Hirschman cycling. Recall the current location of Japan in the cycle: moving in the opposite direction from the U.K. and the U.S., in a halting embrace of "Show Me the Money Corporate Governance" focused on increasing profitability and shareholder returns. Japan's Stewardship Code was heavily influenced by the U.K. Stewardship Code, but the motivation for its introduction was very different from that of its country of origin. ${ }^{175}$ While the U.K. Code's focus was the public interest in restraining excessive risk taking and short-termism, in Japan, the Code was intended to invigorate docile institutional investors and improve corporate governance to support "aggressive" management necessary for Japan's "revitalization strategy." 176

There are multiple ironies buried in this ostensible soft law transplantation story. First, it is noteworthy that Japan chose for its effort to move away from policy channeling and toward increased attention to shareholders interests, a tool originally intended, at least symbolically, in its country of origin to encourage institutional investors to be more patient and provide management with more discretion to consider non-shareholder interests. But unlike the poor fit between the U.K./U.S. conception of stewardship and the actors chosen to advance it (institutional investors), the Japanese Stewardship Code asks institutional investors to promote a shift in the direction of the governance cycle toward capital market completeness-a task to which they are potentially well suited. That the policymakers nonetheless called the effort to tighten Japanese managers' focus on shareholder returns "stewardship" is another irony, though it may go down as a masterstroke of marketing or, more charitably, an attempt to signal the seriousness of the government's and market players' intentions to change the passivity that had characterized the relationship between institutional investors and their portfolio firms. ${ }^{177} \mathrm{~A}$ final irony is that although the adoption of the Japanese Stewardship Code was intended to enliven investor engagement, the language it uses is "milder

${ }^{175}$ Goto, supra note 94, at 365. Japan's mimicking of the U.K. code was not verbatim: for example, Japan omitted portions of the U.K. Stewardship Code that encourage collective stewardship action by institutional investors. Japan is not the only example of an Asian country making ostensible use of the U.K. Stewardship Code for purposes that are highly specific to the host country, rather than its intended purpose in the home country. Singapore also adopted a Stewardship Code for institutional investors. But as in Japan, the corporate governance issues that motivated its adoption bore no resemblance to those in the U.K. See Dan W. Puchniak \& Samantha Tang, Singapore's Puzzling Embrace of Shareholder Stewardship: Successful Secret, (Nat'l Univ. of Sing., Law Working Paper No. 2019/022), https://papers.ssrn.com/sol3/papers.cfm?abstract_id $=3474151$.

${ }^{176}$ Goto, supra note 94 , at 387.

${ }^{177}$ Singapore's Stewardship Codes also have a strong signaling function. Puchniak \& Tang, supra note 175 , at 23 . 
and more nuanced [than the U.K. version]-not encouraging institutional investors to take a tough stance against investee companies." 178

China is one of the few countries in Asia that has yet to adopt a stewardship code, although this should come as no surprise. As we have outlined above, the Chinese system is one in which policy channeling has been fused with capital market completeness through the pervasive and expanding direct participation of the Chinese Communist Party in corporate governance. As possibly the world's most stakeholder-oriented system of corporate governance (with stakeholder interests being defined by the Party and so avoiding the complexity of how to reallocate the division of performance among stakeholders), ${ }^{179}$ and with various organs of the state controlling or influencing a huge swath of the public market, China would seem to have little need for a stewardship code, since the Chinese steward is imbedded in the formal corporate governance structure and overall regulatory environment, rather than exercised through the obligations of investors in the company. In fact, policy makers in China may view a stewardship code as potentially threatening to Chinese corporate governance, unless the code were designed to serve as another reminder that the capital market and the state sector function to serve the Party above all else. If China does adopt a Stewardship Code, it will undoubtedly perform a function similar to the one performed by Singapore's Stewardship Code: signing on to the global stewardship movement without disrupting its state-centered system of corporate governance.

\section{B. The Second Channel: Corporate Purpose}

The second channel through which the Hirschman cycle's current rebound in the direction of policy channeling in the U.S. and the U.K. is funneled is termed "corporate purpose." As we will see, the corporate purpose concept is less a conduit separate from stewardship, than, in the end, two forks that rejoin at the confluence of the current central characteristic of corporate governance: the intermediation of equity through institutional investors.

The corporate purpose debate as currently framed is hardly a new thought. In concept it tracks the very origins of the corporation as a tool or partner of government we discussed in Part $\Pi$, early writing on corporate social responsibility, ${ }^{180}$ which then prominently resurfaced in the academic debate with Margaret Blair and Lynn Stout's somewhat narrower team pro-

${ }^{178}$ Goto, supra note 94 , at 386.

${ }^{179}$ Compare Lucien Bechuk \& Roberto Tallarita, The Illusory Promise of Shareholder Governance, 106 CoRnel. L. REv. 91 (2021) with Colin Mayer, Shareholderism Versus Stakeholderism - a Misconceived Contradiction. A Comment on 'The Illusory Promise of Stakeholder Governance' by Lucian Bebchuk and Roberto Tallarita (Eur. Corp. Governance Inst. Law Working Paper No. 522/2020), https://ssm.com/abstract =3617847.

${ }^{180}$ See, e.g., Howard Bowen, Social Resionsibilities of the Businfssman (1953) (possibly the first academic work proposing what came to be labeled corporate social responsibility, arguing in favor of "the obligations of businessmen to pursue those policies, to make those 
duction approach, ${ }^{181}$ and then more recently and roughly simultaneously in the statements of important establishment players in the corporate governance debate and high profile participants in the political debate. Consider the following statement from the 2020 Davos Manifesto: "[T]he purpose of a company is to engage all its stakeholders in shared and sustained value creation. In creating such value, a company serves not only its shareholders, but all its stakeholders-employees, customers, suppliers, local communities and society at large." 182 A similar framing is reflected in the various efforts we outlined in the Introduction: the 2019 revision of the Business Roundtable Statement on the Purpose of a Corporation, ${ }^{183}$ Martin Lipton's "New Paradigm," 184 and the British Academy project on Reforming Business for the 21 st Century: The Future of the Corporation, ${ }^{185}$ led by Colin Mayer. Perhaps surprisingly in light of the fervor with which the current shareholdersversus-stakeholders debate has taken place, economists do not disagree with the appropriateness of a broad measure to assess corporate performance: the net gain of all those doing business with the corporation. This measure requires a netting of gains and losses ${ }^{186}$-in effect, Kaldor-Hicks efficiency. ${ }^{187}$

For this purpose, imagine again as we did in Part IB a simple corporate income statement. Each line item-for example, sales, wages, cost of goods sold, taxes and net income-corresponds to a different stakeholder: customers, employees, suppliers, government, and shareholders. ${ }^{188}$ In turn, each of these stakeholders interacts with the corporation through a different factor market. If these markets operate efficiently, the distributional decisionswhat portion of the corporate revenue each stakeholder group commandswould be made by markets, with shareholders claiming the residual and bearing the cost and receiving the benefit of managing those inputs effec-

decisions, or to follow those lines of action which are desirable in terms of the objectives and values of our society.").

${ }^{181}$ Margaret M. Blair \& Lynn A. Stout, A Team Production Theory of Corporate Law, 85 VA. L. REv. 247 (1999) (the original statement of the theory).

${ }^{182}$ Klaus Schwab, The Davos Manifesto: The Universal Purpose of a Company in the Fourth Industrial Revolution, (Dec. 2, 2019) https://www.weforum.org/agenda/2019/12/davosmanifesto-2020-the-universal-purpose-of-a-company-in-the-fourth-industrial-revolution (as with most committee draft positions, the framing leaves room for almost anything).

${ }^{183}$ See supra notes 11-13 and accompanying text.

184 "In essence, the New Paradigm recalibrates the relationship between public corporations and their major institutional investors and conceives of corporate governance as a collaboration among the corporation, shareholders and other stakeholders ... ." Lipton, supra note 6.

${ }^{185}$ BrIT. ACAD., supra note 5, at 8; see also Mayer, supra note 4, which set out the foundation for the project. The Enacting Purpose Initiative published an implementation report for boards of directors. Enacting Purpose Inttiative, Enacting Purpose Within the Mod. ERN CORPORATION (2020), https://www.enactingpurpose.org/assets/enacting-purpose-initiative--eu-report-august-2020.pdf.

${ }^{186}$ See generally Marco Becht, Patrick Bolton \& Alicia Röell, 1 Corporate Governance and Control, in HANDbook of THE Economics of FinanCE, 1-109 (George Constantinides, Milton Harris \& René Stulz eds., 2003).

187 See Gilson, supra note 1, at 23.

${ }^{188}$ See $i d$. 
tively. The problem becomes more interesting when different strategies can be used to make the same product, and so with different amounts and characteristics of the inputs. A classic example has been the difference between the strategies of two big-box stores: Costco and Sam's Club, which is owned by Walmart. Although they are both in the same retail business, Costco treats its employees better, paying higher wages, providing health insurance, imposing less burdensome shift scheduling, etc. Costco's explanation for paying more than the factor (labor) market-clearing price is that profits are higher if employees like their jobs and want to keep them ${ }^{189}$ - a jargon-free version of the efficient wage theory. ${ }^{190}$ Sam's Club treats its workers less well but still performs adequately. ${ }^{191}$

With this framing, the inquiry into the corporation's purpose becomes of less consequence. ${ }^{192}$ There is more than one way to run a company; if institutional investors can be persuaded to be proactive in assessing management quality and acting on that assessment-demanding managers who can walk the line between being myopic and hyperopic-we may accomplish more than designing new paradigms. ${ }^{193}$ The plain implication is that in this round of the Hirschman cycle, the real work, if any, will be done by stewardship (i.e., the monitoring and engagement activities of institutional investors) not by legally or symbolically reframing the obligations of corporations. ${ }^{194}$

${ }^{189}$ See id. at 19.

${ }^{190}$ See Carl Shapiro \& Joseph E. Stiglitz, Equilibrium Unemployment as a Worker Disciplinary Device: Reply, 75 Am. ECON. REv. $892-93$ (1985).

${ }^{191}$ For example, Costco had average hourly wages of $\$ 20.89$, while Sam's Club average hourly wages were \$11.23. See Liza Featherstone, Wages Against the Machine, SuAtr (June 27, 2008), http://www.slate.com/articles/business/moneytbox/2008/06/wage_against_the_machine.html. The Costco versus Sam's Club differences in how they treat their employees has become a familiar comparison in the corporate governance debate. See Alex Edmans, Grow the Pif: How Great Companies Del iver Both Purpose and Proftr 43 (2020). The Costco $\mathrm{CEO}$, testifying before Congress, did not explain its strategy as reflecting a broader purpose: "This isn't altruism. ... At Costco, we know that paying employees good wages and providing affordable benefits makes sense for our business and constitutes a significant competitive advantage for us." Michael Corkery, Costco Will Raise its Minimum Wage to $\$ 16$ an Hour, NY Times (Feb. 25, 2021), https://www.nytimes.com/2021/02/25/business/costco-to-raise-minimum-wage-to-16.html\#: :text $=$ costco $\% 20 \mathrm{Will} \% 20$ Raise $\% 20 \mathrm{Minimum} \% 20 \mathrm{Wage}$,Says $\% 20$ $\% 2 \mathrm{D} \% 20 \mathrm{The} \% 20 \mathrm{New} \% 20$ York\%20Times.

192 See Bebchuk \& Tallarita, supra note 179 (addressing the corporate purpose debate).

${ }^{193}$ Martin Lipton, who has played a leading role in framing a new paradigm for corporate law that focuses on purpose and, in particular, on stakeholders, recognized that his agenda ultimately depends on attracting the cooperation of institutional investors. See Symposium, supra note 167, at 23 ("If BlackRock and State Street and Vanguard all come out and say, we're for purpose and culture, we agree with all of this, but then continue to vote for proposals by activist hedge funds, then we don't accomplish anything. There's nothing new in the New Paradigm, and there's really nothing new in the last 30 years. But the competing features of the investment management business have essentially prevented a real resolution of the problem. Unless we can get the major investment institutions to buy into supporting purpose and culture, we will not solve the problem.").

${ }^{194}$ We are skeptical that redesigning the standards defining a board's obligations is likely to accomplish anything significant. First, as the Costco/Sam's Club example in the text suggests, in markets with real-world frictions, differing distributions among stakeholders can be sustainable in the same markets. See Ronald J. Gilson, Charles F. Sabel \& Robert E. Scott, 
Unless institutional investors greatly increase the ambition of their stewardship, the result we expect will be a Hirschman-like disappointment-driven reversal, toward a renewed focus of the governance system on shareholder value maximization.

The Hirschman-like cycle between the binary influences on corporate governance-market completeness and policy channeling-predicts the next direction of reform but not the success of the effort. In terms of the present emphasis on policy channeling to shift the focus of corporate governance from shareholder value maximization in the direction of other stakeholders, we have argued that there are substantial barriers to success, reinforcing our conclusion that addressing distributional concerns is the role of the government- "real governance," not corporate governance. ${ }^{195}$ As we argued in Part III, China has infused its corporate governance system with the "real governance" concerns of the Communist Party, but this hardly seems like a viable or desirable direction of reform for other economies. Addressing distributional issues through corporate governance, even to a far less thoroughgoing degree than is the case in China, runs the risk of making the pie smaller and less fairly distributed. Putting distributional decisions in the hands of boards of directors who, however diverse in their social attitudes or political views, are still made up predominantly of aging, rich, white males ${ }^{196}$ who are not politically accountable for their choices, hardly seems like a

Contracting for Innovation: Vertical Disintegration and Interfirm Collaboration, 109 Colum. L. REV. 431, 494-501 (2009) ("[T]here is more than one organizational response to particular transaction costs. The relation is, at least, one to many[.]"). Professor Colin Mayer suggests that courts will enforce a board's broader fiduciary duty to stakeholders expressed in a charterspecified purpose. See Remarks of Colin Mayer, in Symposium, supra note 167, at 17. American corporate lawyers will understand that the choice between Costco's and Sam's Club's different strategies will be protected by the business judgment rule that instructs courts not to evaluate the business strategies chosen by corporate managers, in effect allocating responsibility for assessing business success to the market, not the courts. Second, if the market concludes that management's chosen pro-stakeholder strategy results in a lower stock price but one that is not Kaldor-Hicks inefficient, the capital market may intervene by generating a hostile takeover bid, or a hedge fund campaign to change the board. Absent a change in the inclination of institutional investors to accept a premium bid or support an activist investor's proxy contest to change the board and hence the strategy, Mayer's corporate purpose will need to be protected by giving existing management the power to protect their control. Third, the easiest way to accomplish this is with a controlling shareholder, who is not accountable to anyone for the corporation's performance.

${ }^{195}$ See also Gilson, supra note 23.

${ }^{196}$ As of 2019 , men held $73 \%$ of S\&P 500 board seats, and about $80 \%$ of S\&P 500 board members were white. See Spencer Stuart, 2019 U.S. Spincer Stuart Board Index 21, 37 (2019), https://www.spencerstuart.com/-/media/2019/ssbi-2019/us_board_index_2019.pdf. The average age of an S\&P 500 board member in 2018 was 63.5. See Kerie Kerstettler, $S \& P$ 500 Trend Report: Board Composition, Diversity and Beyond, Diligentinsights (Apr. 19, 2019), https://insights.diligent.com/board-composition/sp-500-trend-report-board-composition-diversity-and-beyond. Nonetheless, things are moving in the right direction. According to PriceWaterouseCoopers, "2021 saw the most diverse class of S\&P 500 directors ever and signs point to that trend continuing." Maria Castanon Moats \& Paul DeNicola, Four Trends Shaping Corporate Governance in 2022, Harv. L. Sch. F. ON Corp. Governance (Jan. 22, 
sound response, or one that will placate proponents of the effort. And protecting those same directors from market monitoring of their business decisions does not appear likely to improve corporate performance.

\section{Conclusion}

In this Essay, we have used Albert Hirschman's Shifting Involvements to conceptually motivate a broad inquiry into patterns of corporate governance development. The single factor models that currently dominate the governance literature predict a stable Copernican corporate governance solar system, with one or another factor-for example, shareholder value maximization, director primacy, or team production-at its center. Henry Hansmann and Reinier Kraakman's evocatively titled article The End of History for Corporate $\mathrm{Law}^{197}$ forcefully addresses the point in its very first paragraph:

The basic law of corporate governance. . has achieved a high degree of uniformity across developed market jurisdictions. . ..The core legal features of the corporate form were already well established in advanced jurisdictions one hundred years ago, at the turn of the twentieth century... . There is no longer any serious competitor to the view corporate law should principally strive to increase long-term shareholder value. ${ }^{198}$

In contrast, we see not stability but, following Hirschman, a cyclical pattern of oscillations in the relative weights of the two influences on the corporate governance system-capital market completeness, which privileges shareholder value maximization, and policy channeling, which targets distributional and social issues that the government may use corporate governance as a tool to address. We have seen that this pattern is not limited to a particular country. Indeed, we see the same cyclicality across different countries' corporate governance systems, at different points in time, and with the countries moving in opposite directions. The pattern of repeated oscillations in the relative weights of the two influences in corporate governance appears to be driven in significant measure by overreach in both directions: excessive confidence in market mechanisms to provide the optimal mix of incentives and monitoring technologies for corporate managers to maximize shareholder returns, on the one hand, and overconfidence in the ability of regulation to mandate or facilitate corporate solutions to economic and social problems that, at bottom, require direct action through real governance on the other. Failure to meet unrealistic expectations in either realm of cor-

2022), http://corpgov.law.harvard.edu/2022/01/22/four-trends-shaping-corporate-governancein-2022/

${ }^{197}$ Henry Hansmann \& Reinier Kraakman, The End of History for Corporate Law, 89 Geo. L. J. 439 (2001).

${ }^{198}$ Id. at 439 . 
porate governance generates momentum moving the corporate governance system back in the direction from whence it came.

Who gets the better of the argument: Hansmann and Kraakman's expectation that we have settled into a stable system of shareholder value maximization or our account of a cyclical pattern of corporate governance shifting from a focus on shareholder value to a broader focus on corporate stakeholders and back again?

One way to frame the difference is with the corporate governance fixation on equilibria-that there is a stable "natural equilibrium" (or corporate governance model) which, once the system settles, will be durable. We can illustrate this by reference to developments in the study of natural systems, in particular the dominance of change over equilibrium as the normal condition. The ecology of natural environments has been dominated by the concept of a natural equilibrium. From this perspective, we expect the "balance" of nature. However, some students of ecology have come to question the belief that systems return to such a natural environment after a disruption. ${ }^{199}$ From this perspective, change is constant and participants in the system react to other changes in idiosyncratic ways. Thus, the normal state of nature is one of change-a succession of short-lived and very different equilibria. ${ }^{200}$ Our study suggests that governance systems display similar characteristics: they are not stable and respond in idiosyncratic ways to external developments, such that context matters a great deal. This lesson should generate a measure of humility and historical perspective in proponents of corporate governance reform of all stripes.

${ }^{199}$ See, e.g., Daniel B. Botkin, Discordant Harmonies (1990). Daniel B. Botkin, Science and the Global Environment, in Changing the Globai. Environment, 3 (Daniel B. Botkin et. al. eds 1989).

${ }^{200}$ Newspaper accounts of this potential change in understanding provide an accessible source. See William K. Stevens, Balance of Nature? What Balance is That?, NY TImes, Oct. 22, 1991, at C4; William K. Stevens, Eye on Nature: The Real Constant is Eternal Turmoil, NY Timrs, July 31, 1990, at C1. 